KOVÁCS PÉTER

\title{
ADATOK A TETRARCHIA-KORI KATONAI ÉPÍTKEZÉSEKRÓL PANNONIÁBAN
}

A tetrarchia kora jelentôs változásokat hozott Pannonia életében mind közigazgatásilag, mind katonailag. A provincia késô római limesének kutatása során a legutóbbi idôkig több toronytípust (legyezô-, illetve patkóalakú, köralakú tornyok) sikerült elkülöníteni, valamint építési idejük is hozzávetôlegesen meghatározhatóvá vált. A tetrarchia-kor építkezéseit Pannoniában, bár antik forrás is említi (Chron. min. I. p. 230), mindmáig véglegesen nem sikerült elválasztani az auxiliaris castellumokban eltekintve Intercisától, ahol egy fossát lehet erre a korra keltezni. ${ }^{1}$ Esetleg a tetrarchia korára keltezhetô még az aquincumi legióstábor porta praetoriájának átépítése. ${ }^{2} \mathrm{~A}$ tetrarchia korára keltezhetô továbbá még egy jellegzetes pannoniai ôrtorony-típus. ${ }^{3}$ Erre a korra eddig még egyetlen téglabélyeg-típust sem sikerült biztosan elkülöníteni. ${ }^{4}$ Jelen helyen a korábbi ásatási eredmények összefoglalása mellett Hydatius Pannoniára vonatkozó adatával foglalkozom, valamint kísérletet teszek egy régóta publikált, de jelentőségében fel nem ismert ásatási eredmény alapján egy új pannoniai oldaltorony-típus elkülönítésére.

${ }^{1}$ Gabler D.—Lórincz B.: Limestáborok. in: Pannonia régészeti kézikönyve. Budapest 1990. 94103, 100; E. Tóth: Zur Chronologie der militärischen Bautätigkeiten des 4. Jh. in Pannonien. MittArchInst 14 (1985) 121-136, 121. Intercisa: B. Lörincz-Zs. Visy: Die Baugeschichte des Auxiliarlagers von Intercisa. in: Roman Frontier Studies 1979. BAR IS 71. Oxford 1980. 681-701, 688. A tetrachia korára keltezhetô még a matricai auxiliaris tábor principia szentélyének második padlószintje: $P$. Kovács: Excavations in the principia of Matrica (Százhalombatta), 1995-1997. in: Roman Frontier Studies XVII/1997. Zalau 1999. 407.

${ }^{2}$ K. Póczy: A porta praetoria feltárása az aquincumi legióstáborban - The excavation of the porta praetoria in the Aquincum legionary camp. BudRég 24 (1976) 79-89; K. Póczy: Zur Baugeschichte des Legionslagers von Aquincum zwischen 269 und 320. in: Akten des 14. Internationalen Limeskongresses. Wien 1990. 689-702. A kapu rekonstrukciójához lásd Chr. Ertel: Zur Rekonstruktion der porta praetoria des Legionslagers Aquincum. in: Roman Frontier Studies XVII/1997. Zalau 1999. 397-403.

3 Visy Zs.: Római jelzőtornyok és a limes-út Intercisa térségében - Römische Wachttürme und die römische Limesstrasse im Raum von Intercisa. ArchÉrt 107 (1980) 166-175.

${ }^{4}$ Lörincz B.: A hadsereg építkezései. A bélyeges téglák. in: Pannonia régészeti kézikönyve. Budapest 1990. 84 . 


\section{Új erödök Pannoniában és Hydatius Fastija}

Hydatius Fastijának 294. évi bejegyzése alapján tudjuk, hogy his coss. castra facta in Sarmatia contra Acinco et Bononia (Chron. Min I, 230). A táborok építésének különlegességét mutatja, hogy ez az egyetlen ilyen jellegú korai adat chronicában. Az elsônek még a helye is vitatott, ${ }^{5}$ az Acumincummal szemben Titelnél feltételezett római tábor helyét a mai napig nem ismerjük (Acinco értelmezése körüli vita - Acumincum vagy Aquincum). ${ }^{6}$ Annyi bizonyos, hogy az erődök a Duna partján is megépülhettek, egyrészt a contra elnevezés, másrészt a köln-deutzi erőd elveszett építési felirata alapján (CIL XIII 8502- cf. még ILS 2784), amelynek szövege szerint a Rajna túlparti erőd is in terris eorum (sc. Francorum) épült meg Constantinus uralkodása alatt. ${ }^{7}$ Ezt az adatot erôsíti azon Cassius Dio-hely is, amely a markomann háborúk után a dunai szigetek kiürítését is előírta a szarmaták számára (LXXI, 19, 2 a 76 stadionra vonatkozó (a Dunától számított kiürítendő sáv) hely: LXXI, 16, 1). Ásatások (vagy elégtelen ásatások) hiányában eddig mindössze csak a begecsi ellenerôd helye vált ismertté a Duna bal partján, ahol régebben folytak is régészeti kutatások, de a táboralaprajz csak a legutóbbi évek kutatásai során vált ismertté egy régi légifotó alapján. ${ }^{8}$ A század elején elókerült félköríves falszakasztól keletre és nyugatra is a Dunával párhuzamos falszakaszokat tártak fel, ahogy az a szerencsésen megmaradt ásatási helyszínrajzon látható. Ez alapján nagy valószínúséggel a 8,5 m hosszú félköríves falszakasz egy köralakú oldaltoronyhoz tartozhatott, nem pedig saroktorony volt. ${ }^{9}$ Kör alakú oldaltornyok azonban a pannoniai limesszakaszon csak a IV. sz. közepén terjedtek el (lásd feljebb). Így, nemrégiben egy régebbi légifotó alapján kör alakú oldaltornyokat sikerült beazonosítanunk a szintén barbaricumi felsőgödi tábor esetében. ${ }^{10}$ Utóbbi tábor az itt előkerült OFAR típusú bélyeges téglák alapján legkorábban a IV. sz. közepére keltezhetô. ${ }^{11}$ Mindezek miatt jogos a feltételezés, hogy a begecsi tábor esetében az esetleges kör alakú oldaltornyok utólagos hozzáépítés eredményei.

5 S. Soproni: Contra Acinco et Bononia. Bemerkungen zu den Fasti des Hydatius. Studien zu den Militärgrenzen Roms II. Köln 1977. 393-397; Tóth E.: Vitás kérdések Pannonia 4. századi történetében I. Contra Acinco et Bononia. AntikTan 27 (1980) 131-137= Contra Acinco et Bononia. ArhVestnik 33 (1982) 68-78.

6 TIR L 34. Budapest 1968. 112.

${ }^{7}$ M. Gechter: Zur Überlieferung der Bauinschrift des Kastells Divitia (Köln). Kölner Jahrbuch 24 (1991) 377-380.

${ }^{8}$ A legutóbbi összefoglalás a légifotóval: G. Bertók: Contra Bononia- a Roman fort in the Barbaricum. in: Forschungen zur Archäologie im Land Brandenburg 3 (1995). Luftbildarchäologie in Ost- und Mitteleuropa. 219-226.

${ }^{9}$ Gubitza K.: A begecsi romok. Bács-Bodrog vármegyei történeti társulat évkönyve 23 (1907) 8082, Dudás Gy.: A begecsi ásatásokról. ArchÉrt 22 (1902) 350; P. P. Vellenrajter: Castellum Onagrinum. Rad Vojvodanskih Muzeja 7 (1958) 126-132 (alaprajzzal); V. Dautova-Ruševljan: Zaštitno iskopavanje antičkog lokaliteta „Kova” kod Begeča. Rad Vojvodanskih Muzeja 21-22 (1972-1973) 141-152; D. Dimitrijević-M. Gabričević-D. Vilotijević: „Kuva”, Begeč-rimsko utvrđene Onagrinum no levoj obali Dunava. ArhPregled 16 (1974) 86-89.

${ }^{10}$ Kovács $P .:$ Római kor. in: Pest megye régészeti monográfiája. Szerk.: Torma I. (s. a.)

${ }^{11}$ S. Soproni: Der spätrömische Limes zwischen Esztergom und Szentendre. Das Verteidigungssystem der Provinz Valeria im 4. Jahrhundert. Budapest 1978. 79—81. 
A Consularia Constantinopolitana 294-es, Pannoniára vonatkozó adatát már sokszor és sokan értelmezték. ${ }^{12}$ Véleményem szerint az egyik legfontosabb tény, hogy Hydatius adata nem a táborok neveit tartalmazza. A contra Bononia et Acinco kifejezés ablativusai a vulgáris latin egyik sajátosságából fakadóan (casusok felcserélése) állnak a contra + accusativus helyett, tehát nem locativusokról van szó. ${ }^{13} \mathrm{~A}$ meghatározás csak arra vonatkozik, hogy hol épültek táborok: Sarmatiában. Ezt a Not. Dig. is csak megerősíti, mivel a begecsi tábor esetében (Occ. XXXII, 41) a contra Bononiam in barbarico in Castello Onagrino meghatározás szerepel. Hasonló meghatározás máshonnan is ismert még a katonai sematizmusból (pl. Or. XLI, 33 contra Margum in castris Augustoflavianensibus-utóbbi másik ismert neve Constantia-Priscus IV, 7214). Ezekből következőleg a Cons. Const. adata szerint erődök épültek a Duna túl partján Bononiaval és Acincummal szemben. A Not. Dig. Contra Aquincumját nem lehet automatikusan azonosítani a Fastiban említettel. Véleményem szerint abból csak annyi következik, hogy a két említett hellyel szemközti szakaszon erődöket építettek. Ez nem feltétlenül jelenti az erőddel pontosan szemközti helyet. A másik igen fontos tény, hogy ezáltal Acincum esetében az erőd neve sem bizonyos. Mindezek alapján a következő fontos kérdés, hogy a szóbanforgó Acincum Aquincummal, vagy Acumincummal azonosítható. Véleményem szerint számos filológiai és régészeti adat ellentmond a Fasti Acincumjának Acumincummal való azonosításának:

I. 1. Hydatius adatával már sokan foglalkoztak, alapos filológiai vizsgálata azonban elmaradt. A ránk Hydatius neve alatt hagyományozott mú eredetileg is több részbő́l állt. ${ }^{15} \mathrm{~A}$ krónika elsố része egy Roma városi, Fasti Capitolinivel rokon latin nyelvú forrásból származik, amely az első consuloktól kezdve évenkénti lebontásban közölte jórészt csak a consullistákat. A mú középső része származik a Konstantinápolyban keletkezett Consularia Constantinopolitana rövidített változatából Kr. u. 330-tól kezdve 389-ig, rendszeres vezetése azonban ennek is csak 367-ben kezdődött. Ezt a múvet folytatta maga Hydatius 390-tôl 468-ig. A mú Constantinus előtti bejegyzései igen ritkák, jórészt csak nagyobb keresztény (Jézus születése, megfeszítése), irodalomtörténeti (pl. Cicero halála), Roma városi (ludi, innen látható természeti csodák) események említésére szorítkoznak. A múben az egyetlen, katonai tábor építésére vonatkozó adat a 294. évi bejegyzés. Régóta ismert, hogy a minket

${ }^{12}$ Lásd feljebb Soproni S. és Tóth E. tanulmányait, valamint Nagy L.: Az eskü-téri római erôd. Budapest 1946. 107-109, A. Mócsy: Pannonia and Upper Moesia. London-Boston 1974. 269; J. Fitz: Contra Acinco et Bononia. Alba Regia 17 (1979) 354.

13 ThLL IV/4. 738-752, de különösen: 738, 30-35.

${ }^{14}$ Soproni: i. m. (11. j.) 124; G. Patsch: Constantia. in: PWRE VII. Stuttgart 1900. 7; M. Dordević: Contributions to the study of the Roman limes in South Banat. in: Roman limes on the Middle and Lower Danube. Belgrade 1996. 125-133.

${ }^{15}$ Chron. Min. I. 199-203; R. W. Burgess: The chronicle of Hydatius and the Consularia Constantinopolitana. 1993. Hydatiusra vonatkozóan: Hydace, Chronique I-II. Sources Chrétiennes 218-219. Paris 1974. 
érdeklő tetrarchia-kori adatok azonban más forrásból származnak. ${ }^{16}$ Érdemes megfigyelni, hogy a bejegyzések száma a 280-as években hirtelen megugrik (Diocletianus uralkodása alatt 11 bejegyzés). Ezek miatt a 294. évhez bejegyzett adatot a tetrarchia-kori adatok összefüggésében kell vizsgálnunk. Ezen idôszak (már a 280-as évek elejétól kezdve!) alatti bejegyzések ugyanis a Cons. Const. máshonnan ismert adataival ellentétben nem pontosak, részben pedig mások, mint a Hydatius neve alatt fennmaradtak. Utóbbiak ugyanis egy éves elcsúszással kerültek bejegyzésre. Így Maximianus trónrakerülése a 286. évhez, Galerius trónra kerülésének éve 291-hez 293 helyett, a 292-es napfogyatkozás 291-hez lett feljegyezve, így lett Diocletianus ármaximáló rendeletének ideje 302301 helyett, Diocletianus lemondása pedig 304 305 helyett. Ezek miatt az a feltevés is jogos, hogy a 294. évi feljegyzés is téves évhez került bejegyzésre. A legutolsó csúszás a 319 májusi napfogyatkozás 318. évi bejegyzése. Ez az esemény egyébként csak a nyugati provinciákból, legjobban Galliából volt látható. A 280-as évek, és a 290-es évek elsố felének adatainak egy részét egy évvel későbbre (Tacitus halála, Probus halála, Maximianus trónrakerülése, a 292-es napfogyatkozás), a késôbbieket pedig általában egy évvel korábbra keltezték. Így a 294. évi esemény feltételezhetô éve inkább 293, amikor Diocletianus hosszú pannoniai tartózkodására vannak adataink, lugioi tartózkodása ez év novemberére keltezhető (Cod. Iust. IX, 20, 10-11).

Az adatok eddigi vizsgálata során elkerülte a figyelmet a következő évi adat Carpok Romaniába (sic!) való befogadásáról. Ez az adat szintén Pannoniára vonatkozik, mivel más forrásból (Aur. Victor, Caes. 39, 43, Eutrop. VIII, 25, 2, Ammianus XXVIII, 1, 5) is ismert, hogy Galerius Pannoniában telepítette le ôket, valószínúleg 296-ban. ${ }^{17}$ Ugyanígy szintén nem birodalmi vonatkozású bejegyzésnek kell tekintenünk a 332-334. évi eseményeket, amelyek kapcsán a szintén pannoniai vonatkozású gótok elleni hadjáratot, illetve a Sarmatae liberi befogadását említi forrásunk. Az elôbbi bejegyzés különös fontosságú, mivel ezen a helyen említik meg Sarmatiát még egyszer Hydatius múvében: in terris Sarmatarum. A Sarmatae recensioja esetében pedig ugyanazt a Romania kifejezést használták, amit a Carpi esetében. A múben a Romania szó csak ezen a két helyen fordul elő, így jogos az a feltételezés, hogy a Diocletianus-korra vonatkozó forrást Hydatius még ezzel az időszakkal kapcsolatosan is felhasználta. Ezek alapján a Sarmatiában épített táborokra vonatkozó adatnak nem kellett feltétlenül birodalmi fontosságúnak lennie. Az építkezés propagandisztikai fontosságát egyébként sem Sirmium császári székhellyé válása, hanem sokkal inkább nagyobb erődöknek szarmata földön való megépítése okozhatta.

2. A fentiek alapján semmiféle szövegfüggés sem bizonyítható a Cons. Const. és a Not. Dig. in Sarmatia és in Barbarico megjegyzése és ez alapján a két forrás között. Egyébként sem tartom valószínúnek, hogy a birodalmi sematizmus készítói

${ }^{16}$ O. Seeck: Consularia Constantinopolitana. in: PWRE III. Stuttgart 1899. 2459; id., Hydatius. in: PWRE IX. Stuttgart 1916. 41.

${ }^{17}$ Mócsy: i. m. (12. j.) 272; J. Kolendo: in: Hommages a M. Renard II. Bruxelles 1969. 378—. 
az egyes provinciákra vonatkozó adatokat ne hivatalos (udvari kancellária- a módosítások legalábbis ezt mutatják) feljegyzésekből használták volna fel. A Notitia in barbarico megjegyzését Contra Aquincum és Castellum Onagrinum (Occ. XXXII, 41, XXXIII, 48) esetében más okozhatta, nem a Hydatius obskurus nyugati forrásától való szövegfüggése. Ennek oka pedig az lehetett, hogy a két tábor a barbaricumi római katonai létesítmények közül a legnagyobb méretúek voltak (az eskü-téri erôd első periódusa jóval nagyobb lehetett az ismert 2.-hoz képest-lásd lejjebb), ráadásul a contra helynevek közül egyedül Contra Aquincum (és a jóval késóbbi építésú Tautantum) nem balparti hídfóállás. Ez okozhatta a táborépítések megjegyzésének szükségességét is, nagyobb táborokat (Hydatius forrása szerint castra és nem castella!) építettek az ellenség földjén a császár jelenlétében (lásd Diocletianus lugioi tartózkodását).

3. Nem mond ellen a topográfiai felsorolásnak Hydatius bejegyzése, mivel az a Notitiával megegyező módon É-D-i irányban haladva említette az erődöket.

4. Soproni feltételezése alapján a szerémségi limes-szakasz megerósítése Sirmium 293-as császári székhellyé válása miatt vált szükségessé. Ezt a kérdést korántsem egyöntetúen ítélik meg. ${ }^{18} \mathrm{Az}$ itt kiadott császári rescriptumok alapján még nem bizonyítható ugyanis, hogy Sirmium már ebben az idôpontban székhellyé vált.

5. Külön vizsgálatra szorul, hogy indokolt-e az Aquincum-Acumincum helynevek felcserélhetősége a Notitia Dignitatumban és Hydatius Fastijában. Vizsgálatra szorulnak az antik szerzók feltételezett Acumincum-Aquincum tévesztései is. Ptolemaios adata (II, 15, 5), mely szerint a legio II adiutrixot Acumincum mellett említette, nem a két helynév összetévesztéséból származik, hanem nagy valószínúséggel a legio I. századi szerémségi tartózkodását említi meg. ${ }^{19}$ Az Acumincumnál való említés Sirmium és Acumincum felcseréléséből származhat. ${ }^{20}$

Sokkal problematikusabb Ammianus Marcellinus adata a 359-es év eseményeirôl (XIX, 11, 8). ${ }^{21}$ II. Constantius Sirmiumban értesült a Limigantes háborús készülődéséről, majd ennek hírére seregével Valeriába vonult. A következő hely kulcsfontosságú lehet a hely megértése szempontjából. A Limigantes egyes kéziratok szerint (BG) Pannoniába, mások szerint Pannoniákba készültek betörni. Ha BG hagyománynak van igaza, akkor a támadás várható iránya csak Pannonia II lehetett. A másik esetben sem tételezhetô fel azonban, hogy mindkét provinciát külön-külön támadták volna meg, vagy a támadás feltételezhető iránya Aquincum lett volna, mivel inkább a két provincia (Valeria és Pannonia II) közös határszakaszának megtámadása valószínúsíthetőbb. Ezek után küldött követeket a szarmatákhoz a császár

${ }^{18}$ M. Mirković: Sirmium - its history from the I century A. D. to 582 A. D. in: Sirmium I. Beograd 1971, 36; W. Seston: Dioclétien et la tétrarchie. Paris 1940. 235.

${ }^{19}$ Lórincz B.: Legiok. in: Pannonia régészeti kézikönyve. Budapest 1990. 71; M. Mirković: The inscriptions from Sirmium and its territory. in: Sirmium I. Beograd 1971. Nr. 12, 33 (=CIL III 10224).

${ }^{20}$ Fröhlich R.: Acumincum vidéke és a régi római limes II. ArchÉrt 12 (1892) 115-116.

${ }^{21}$ O. Seeck: Regesten der Kaiser und Päpste. Stuttgart 1919. 206. 
egy közelebbról meg nem határozott helyre. Majd ennek nyomán került sor Acimincumnál a barbárok nevezetes fogadására. Ezt a helyet a korábbi megállapítások szerint szövegromlás feltételezése alapján Aquincummal azonosították. ${ }^{22} \mathrm{Az}$ azonosítás azonban korántsem egyértelmú. Egyes kéziratokban (BG) Acunincum helynév szerepel. Ez a két kézirat azonban nem a két legrégibb (VM), amelyek viszont az Acimincum alakot hozták. Kérdéses azonban, hogy valószínú-e, hogy a másolók a közismert Aquincum helyett az alig ismert Aciminicum helynevet hagyományozták volna. Mindezek alapján a következő lehetőségek merülnek fel:

a. Valóban Ammianus keverte össze a helyneveket. Ennek oka lehetett volna, hogy a korábbi harci cselekményekre a Tisza torkolatvidékénél került sor (XVII, 11, 3), ezért tévesztette volna őket össze Ammianus. Ha ez az eshetőség igaz, akkor sem lehet bizonyíték Hydatius forrásának névtévesztésére.

b. Másolók tévesztették volna ôket össze és az Acunincum hagyomány az igaz, amely viszont Aquincumból származik.

c. A feltételezésekkel szemben ténylegesen Acumincum mellett került sor az eseményekre. Véleményem szerint ezt a lehetôséget sem szabad elvetnünk, mivel a Limigantes korábbi központja éppen ezen a vidéken, a korábbi hadjáratokra is ezen a vidéken került sor (cf. XVII, 11), nem véletlenül viselték az Amicenses (= Acumincenses) nevet egyes törzseik. A Limigantes elhagyták az újonnan kijelölt szállásterületüket (valahol az Alföld területén), de nem zárható ki az a lehetôség, hogy ünnepélyes megadásukra felügyeletük régi központjánál került volna sor.

Ezek mellett külön kell vizsgálni Hydatius múvét és a birodalmi sematizmus esetét. Az eddigi feltételezések szerint a Cons. Const. (mint korábban láthattuk nem ez, hanem Hydatius egy másik forrása), valamint tôle függóen a Not. Dig. többszörösen és áttételesen is összekeverte volna a két helynevet. Elsőnek tehát a Consularia, majd ôt követve a Notitia. Sót a Not. Dig. nemcsak valeriai listájába került volna át ez a névtévesztés (elsőként persze azt kellett volna bizonyítani, hogy külön provinciák listájának készítésére egyszerre került volna sor), hanem milites Acincenses említésével a germaniaiba is. Ezt a Notitia készítésének kutatói akár az ún. „rétegelmélet", akár a szinkronitás hívei nem támasztották alá. ${ }^{23}$ A két helynév antik névváltozatai (talán Ammianus kivételével) nem keveredtek össze (Not. Dig. XXXII, $7=26,16=35$, It. Ant. 242, 2). A Notitia kézirataiban a következő névváltozatok fordulnak elő: Aciminci, Acimirci, Acimnici, Acimmci, Acimici. Erre a -mi szótagnyi különbség nem is igen ad lehetőséget, sőt Acimincum esetében a névváltozat másképpen való antik rövidítésére van adatunk (Amm. XVII, 13, 19: A(cu)micenses). ${ }^{24}$ A Tab. Peut. (Seg. V. 3) és a Ravennai Geográfus (IV, 20) jóvoltából fennmaradt

22 Mócsy A.: A Constantinus-dinasztia kora. in: Pannonia régészeti kézikönyve. Budapest 1990. 48.

${ }^{23}$ D. van Berchem: L'armée de Dioclétien et la réforme Constantinienne. Paris 1952. 93-97; S. Soproni: Beiträge zur Frage der Liste von Valeria der Notitia Dignitatum. Acta ArchHung 26 (1974) 5970.

${ }^{24}$ Mócsy: i. m. (12. j.) 279. 
Acunum névváltozat csak a Tabula Peut. mint forrás felhasználását bizonyítja a pannoniai helynevek esetében. A Ravennai Geográfus nyilvánvalóan romlottan hagyományozott helynevet vett át, amit az is bizonyít, hogy Cumunion formában még egyszer hozta múvében Acumincum nevét (IV, 19). Hasonlóan két névváltozatot adott meg az ismeretlen szerző a szomszédos Ad Labores esetében is. A Tab. Peut., mint forrás, felhasználását bizonyíthatják a valeriai helységnevek (IV, 20) között felsorolt szerémségi limes-szakasz helynevei. Ezt mutatja, hogy mindkét forrásban még nem szerepel Valeria provincia, ellenben Valeria Media provinciát feltüntetik, az Acunum helyneven kívül mindkét múben még a Malata név szerepel, pedig Malata táborát már a tetrarchia-korban Bononiává nevezték át. ${ }^{25}$ Ugyanez igaz Lugio-Florentia esetében is. Fontos továbbá, hogy a térképen ezen szakasz alá lett beírva az Inferior szó, ami esetleg megindokolhatja a Ravennai Geográfus tévedését a helynevek Valeria alatti felsorolását illetően. Az Acunum névváltozatot esetleg a szorosan egymás mellé írt -IMINCVMVNVM kurzív vagy minuszkuláris betúk téves olvasatában kell keresnünk.

Aquincum esetében azonban az antik irodalmi (különösen a késórómaiak: It. Ant. 245, 7, Not. Dig. Occ. IX, 19, VII, 101, XXXIII, 48, 54, 65, XLI, 25, Sid. App. V, 107, Amm. 30, 5, 13-14, Chron. Min. I, p. 230, 242) és epigráfiai adataink (CIL VIII 2826, 25740, RIU $1256^{26}$ ) is folyamatosan hagyományozták a helynév Acincum névváltozatát. Hydatius Fastijának középső részében a 375-ös év eseményeinek kapcsán fordul elő a helynév másodszor a múben: in civitate Acinco. Ez valóban más forrásból származik, mint a 294-es, itt a Chron. Paschale is (amely az eredeti latin nyelvú Cons. Const. görög fordítása (Chron. Min. I. p. 199)) említi Aquincumot. ${ }^{27}$ Mindezekbő́l nehezen vonható le mindenféle újabb bizonyíték nélkül, hogy a 294. évnél említett Acincum ne Aquincummal volna azonosítható. Ugyanez a helyzet a Notitia helynevei esetében is. Az Aquincummal való azonosítást elvetôknek kellene ugyanis a másik azonosítás mellett bizonyítékot felmutatni és nem fordítva. Többszörös és áttételes szövegromlást feltételezni minden konkrét bizonyíték nélkül a filológiában is indokolatlan.

II. Sok régészeti adat magának a Titelnél feltételezett ellenerőd létének is ellentmond:

1. A Notitiában egyetlen olyan helynév sincs, amely azonosítható volna Contra Acumincum eródjével. A Notitiában említett milites Acincenses germaniai (Andernach) egység, amely ráadásul egy pseudocomitatensis legio, (Occ. VII, 101, XLI, 25) Contra Acumincumra vonatkoztatása aligha bizonyítható, ${ }^{28}$ mivel a fentiek alapján a

\footnotetext{
${ }^{25}$ E. Tóth: Provincia Valeria Media. Acta ArchHung 41 (1989) 197-226, 200-203, 207.

${ }^{26}$ Utóbbi helyes olvasatához (in Acinco): Kovács P.: Civitas Eraviscorum. Antaeus 24 (1997-1998) 278. n. 3 .

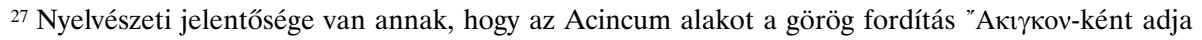
vissza.

${ }_{28}$ Soproni: i. m. (11. j.) 129. Összefoglalólag: A. Alföldi: Der Untergang der Römerherrschaft in Pannonien II. Leipzig 1926. 73-78; D. Hoffmann: Das spätrömische Bewegungsheer und die Notitia Dignitatum. Epigraphische Studien 7. Düsseldorf 1970. I. 342, II. 71, Anm. 627.
} 
feltételezett erőd neve sem ismert, ráadásul ebben esetben elóbb az Acincum-Acumincum névtévesztést a Not. Dig. esetében is bizonyítani kellene.

2. Régóta feltételezik a titeli fennsíkon egy római tábor létét. ${ }^{29}$ Erre a feltételezésre egy Marsigli által lerajzolt, a Titeli fennsíkon levő sánc, valamint a titeli középkori romokból előkerülő faragott (pl. felirat nélküli szarkofág) és feliratos római kőemlékek (többségük mérföldkő!) szolgáltathattak alapot (CIL III 3254, 3255= $=10242,3256,3257=10244,3724-3725,3737,64701=10653,64702=10633,64703$ =10638, 64704=10197, ILJ 1041), amelyek közül a múlt század elején az MNM-be kerülteket állítólag a helyi katonaság találta a fennsíkon egy erôsségben (Dimitrijević, i. m. 153, Anm. 47). Jónéhány esetben azonban a kőemlékek másodlagos beépítését teljes épségük kizárja. Gyanús továbbá az a tény is, hogy közülük több márványból faragott. A Marsigli-féle sánc, amelyet a titeli fennsíkon ábrázoltak a város mellett, a közelmúltban feltárt és publikált bronzkori földvárral (mai neve - Feudvar — is e magyar szóból származik) azonosítható. ${ }^{30}$ A feliratokat valószínúleg a középkorban hozathatták át ide a titeli prépostok (CIL III p. 420, 454). ${ }^{31}$ Másodlagos lelóhelyú feliratos kôemlékek léte önmagában aligha lehet bizonyító erejú egy római katonai objektum létéhez. Megdöbbentő igazából az, hogy publikált római tárgyi emlékeket nem ismerünk innen (még import tárgyakat sem)..$^{32} \mathrm{Az}$ egyetlen római korból származó aranyéremkincslelet (nagyobb része elkallódott, a megmaradt érmek Gratianusé, Arcadiusé és Theodosiusé), amelyet hajósok találtak Titelnél a Tisza partján (nem a fennsíkon!) sokkal inkább a hunokhoz köthetô, mint egy római táborhoz, amelyet a feltételezések (Soproni S.) szerint már a IV. sz. közepén feladtak. ${ }^{33}$ A Magyar Nemzeti Múzeum Éremtárába a múlt században került be néhány máig publikálatlan érem ajándékozás révén Titelről, a Tisza partjáról, illetve Titel megnevezetlen környékérôl (leginkább a Duna jobb parti római területekról) (MNM Éremtár 64/1882 (Const. Magnus kisbronz), 116/1882 (Vesp. középbronz, Const. Magnus kisbronz, 2 Const. Iunior kisbronz), Titel és környéke: 211/1882 (1 ezüst és

${ }^{29}$ Desjardins E.-Rómer F: A Magyar Nemzeti Múzeum római feliratos emlékei - Les monuments épigraphiques romains dans le Musée National Hongrois. Budapest 1873. 48; TIR L 34. Budapest 1968 112; D. Dimitrijević: Die Häfen der classis Flavia Pannonica des Donausektors von Bassianae (TaurunumCusum). in: Roman limes on the Middle and Lower Danube. Belgrade 1996. 143-157, 152-154.

${ }^{30} \mathrm{~B}$. Hänsel-P. Medović: Vorbericht über die jugoslawisch-deutschen Ausgrabungen in der Siedlung von Feudvar (Gemeinde Titel, Vojvodina) von 1986-1990. Bronzezeit-vorrömische Eisenzeit. BRGK 72 (1991) 45-204; S. Nebehay: Prähistorisches bei Marsigli. Archaeologia Austriaca 65 (1981) $75-88$.

${ }^{31}$ Borovszky S.: Bács-Bodrog vármegye I. Budapest 1896. 164-169; II, 92.

${ }^{32}$ D. Gabler: Zu Fragen der Handelsbeziehungen zwischen den Römern und den „Barbaren” im Gebiet östlich von Pannonien. in: Römer und Germanen in Mitteleuropa. Berlin 1975. 87-121, 114, Nr. 184; O. Brukner: Rimski nalazi u jugoslavenskom delu Barbarikuma - Baćka i Banat - Die römische Funde im jugoslawischen Teil des Barbaricums - Baćka und Banat. ArhVestnik 41 (1990) 199-216, 205.

33 Tömörkény I.-Harsányi P: A szegedi múzeumba került régipénz-leletek. Numizmatikai Közlöny 11 (1912) 15; I. Bóna: Das Hunnenreich. Budapest 1991. Abb. 69. 
14 meghatározhatatlan kisbronz)). ${ }^{34}$ Titel területén újonnan végzett kutatások során őskori (Titel-Kálvária-tell) és szarmata településmaradványokat és sírokat (a vasútállomás közelében) figyeltek csak meg. ${ }^{35}$ A valóban titeli lelőhelyú érmek, különösen a kopott Vespasianus középbronz, innen származhatnak. Római objektumokat azonban nem találtak sem a városban, sem a fennsíkon. ${ }^{36}$ Összegezve: A régészeti adatok máig sem támasztják alá egy római katonai erôsség (akár hadjárat során használt földtábor) létét.

3. A kérdéses területre vonatkozóan igen részletes leírást ad Ammianus Marcellinus a 358-as Limigantes elleni hadjárat kapcsán (XVII, 13, 4). ${ }^{37}$ Valószínúnek látszik, hogy az Ammianus által említett sziget a titeli fennsíkkal azonosítható. A Tisza-torkolat leírásakor egyetlen túlparti erődöt sem említ, ráadásul leírása szerint - a túlpart nehezen való támadhatását akár római, akár barbár részról külön hangsúlyozta Ammianus - az a mocsarak miatt szükségtelen is. A Duna jobb parti részek pedig a Fruska Gora nyúlványai miatt hirtelen emelkednek nagyobb magasságba, ami szintén indokolatlanná teszi a partszakasz különleges megerősítését. ${ }^{38}$

4. Titel nem a Duna, hanem a Tisza partján terül el a Béga torkolatánál több mint $8 \mathrm{~km}$ távolságra Acumincumtól (Stari Slankamen). Ezért a feltételezett erőd legfeljebb egy Tisza túl parti erőd contra tábora lehetne.

5. A Szalánkemén-Acumincum azonosítás már Fröhlich R. óta nem túnik teljesen biztosnak még az ásató, D. Piletić, szemében sem, aki egy nagyobb római erősség hiányát hangsúlyozta a mai Stari Slankamen térségben. A legutóbbi idókben történt meg a korábbi ásatások leleteinek, stratigráfiájának feldolgozására, publikálására. ${ }^{39}$ Ennek során kitûnt, hogy a Gradinán három nagyobb korszak különíthtô el: LT oppidum, IV. sz-i római erôsség, illetve középkori vár. A római leletek alapján úgy látszik, hogy a legkorábbi időkben a római erődöt a LTD oppidum helyére építették,

${ }^{34}$ Ezúton köszönöm Torbágyi M. szíves segítségét. Valamennyi érem a pancsovai Schwerer J. ajándéka, vagy közvetítése révén került a múzeumba.

${ }^{35}$ D. Dimitrijević: Sarmati i rimljani. Šajkaška, Istorija 1. Novi Sad 1975. 43-51, 58; M. Párducz: A nagy magyar Alföld rómaikori leletei — Römerzeitliche Funde des Grossen Ungarischen Alföld. Dolgozatok 7 (1931) 138-139.

${ }^{36}$ Ezúton köszönöm Bertók G. és Vaday A. szíves segítségét.

37 A szarmaták megadásánál említett római tábor csak balparti erôd lehetett, valószínúleg a Margummal szemközti Kovin-Kevevára (Castra Augustoflavianensia-Constantia) erődjével azonosítható: TIR L 34. Budapest 1968. 71; Ortvay T: Margum és Contra Margum. Értekezések a történelmi tudományok köréből. Budapest 1876. 56-; ArhPregled 10 (1968) 184; 11 (1969) 161; M. Vuksan: Kovin-srednjovekovno naselje i utvrdenje-Kovin town- medieval settlement and fortification. Rad Vojvodanskih Muzeja 34 (1997) $175-184$.

${ }^{38}$ Nem véletlen, hogy Acumincum-Bononia közötti nem volt más auxiliaris erôd, míg a Tiszatorkolattól lefelé hasonló távolságon a táborok sûrû́södtek (Rittium-Burgenae-Taurunum).

${ }^{39}$ Fröhlich R.: Acumincum vidéke és a régi római limes I. ArchÉrt 12 (1892) 38-40; D. Piletić: Acumincum i Burgenae- Dva važna uporišta na donjopanonskom limesu-Acumincum und BurgenaeZwei wichtige Schützpunkte am pannonischen Limes. in: Odbrambeni sistemi u praistoriji i antici na tlu Jugoslavije. Materijali XXII. Novi Sad 1984. 138, 142; D. Dimitrijević: Istoćni Srem pod rimskom vlasću. in: Zemun. Beograd-Zemun 1987. 29-52, 35; M. Popović: La forteresse de Slankamen. Starinar 47 (1996) 155-168, 157-159; Dimitrijević: i. m. (29.j.) 149-152. 
a középsô császárkori erôsség nyomai azonban hiányoznak. Az elókerült leletek 90\%-a a IV. századból származik. Ezek miatt vetették fel, hogy a II-III. századi erôd máshol állt.

A legutóbbi időben vetôdött fel, hogy a Budapest Eskü téri erôd Contra Tautantummal (Teutanum) volna azonosítható. ${ }^{40}$ A szerző az Aquincum környéki erődök torlódását elkerülendô Transaquincumot nem erődnek, hanem egy bizonyos túlparti területnek határozta meg kritika alá véve az összes ismert Trans előtagú helységnevet..41 Budapest térségében ugyanis csak két nagyobb balparti erőd ismert, míg az azonosítást követóen három helynevet ismernénk: Contra- és Trans Aquincum, Contra Tautantum. A szerző megállapításaival szemben számos probléma vethető fel:

I. A fenti, Hydatius adatára vonatkozó megállapításaink (nem helynevek) alapján az Eskü téri erôd Aquincumtól való távolsága sem ellenérve, sem bizonyítéka az azonosításnak.

II. A feltárt és általánosan ismertté vált erőd valóban a IV. sz. közepére keltezhetô. Azonban már az elsô publikációk alapján világossá vált, hogy az erődnek van egy korábbi fázisa. ${ }^{42}$ Ezt csak azon érv alapján keltezték a II. sz. végére-III. sz. elejére, hogy a késóbbi periódus 294-ból való. ${ }^{43}$ A korábbi periódusban az elókerült táboron kívüli objektumok (hypocaustumos épület a Piarista gimnázium (ELTE) alatt, Bertalan-féle korábbi falak a táboron kívül a patkó alakú toronynál, a Szirmaiféle köves járószint, épületnyomok a tábortól délre) alapján jóval nagyobb a IV. századihoz képest. Az ismertté vált téglabélyegek alapján is próbálták az erődöt ilyen koránra keltezni.

A Nagy L. által ismertetett és mai általánosan használt alaprajz szerint a korábbi periódus egyik tornyát az Erzsébet híd alapozásakor figyelték meg. ${ }^{44} \mathrm{Ez}$ az alaprajz azonban nem mindenben egyezik meg a Kuzsinszky B. által közzétett eredeti helyszínrajzzal. Az sem tételezhető fel továbbá, hogy az amúgy teljesen szaksze-

${ }^{40}$ Zs. Mráv: Castellum Tautantum. Egy későrómai erőd azonosításának problémájához — Zum Problem der Identifizierung eines spätrömischen Kastells. Savaria 22 (1992-1995) 11-19; id.: Valentinianus ... in ipsis Quadorum terris quasi Romano iuri iam vindicatis aedificari praesidaria castra mandavit (Amm. Marc. XXIX, 6, 2). in: Pannoniai kutatások. A Soproni Sándor emlékkonferencia elóadásai, Bölcske, 1998 október 7. Szekszárd 1999. 77-111, 86, 100, j. 49.

${ }^{41}$ Korábban már így: Nagy L.: Pest város eredete. Tanulmányok Budapest múltjából 3 (1934) 14.

${ }^{42}$ Nagy: i. m. (12. j.) 54-56; Bertalan V:: A belvárosi plébániatemplom mellett folytatott ásatások 1944 nyarán. BudRég 14 (1945) 469—; RégFüz 28 (1975) 48—51=BudRég 24 (1976) 425—426, 330333. képek. Ásatásokról továbbá: Nagy T.: Római kőemlékek Transaquincum területéról. BudRég 15 (1950) 359-380; RégFüz 24 (1971) 29-30.

${ }^{43}$ Der römische Limes in Ungarn. Hrsg. J. Fitz. Székesfehérvár 1976. 123; Visy Zs.: A római limes magyarországon - Der römische Limes in Ungarn. Budapest 1989. 82 - 83; T. Bechert: Römische Lagertore und ihre Bauinschriften. BJ 171 (1971) 276-277. A másodlagos felhasználásban előkerült töredékes Marcus Aurelius-fej aligha keltező lelet, mivel az az Erzsébet-híd alatti nem római kori toronyból került eló: $N A G Y$ : i. m. (12. j.) 26. Nincs arra bizonyíték, hogy a rómaiak egy korábbi helyi táborszentély kultusszobrának töredékét használták volna fel másodlagosan.

${ }^{44}$ Kuzsinszky B.: Újabb kőemlékek az Aquincumi Múzeumban. BudRég 7 (1900) 7. A Kuzsinszky által a szövegben említett $8 \mathrm{~m}$-es mélység csak nyomdahiba lehet, mivel máshol a római falak alapozási mélysége nem érte el még a felszíntől számított $5 \mathrm{~m}$ mélységet sem! 
rúnek látszó helyszínrajz egy teljesen más, hamis toronyalaprajzot közölt volna ${ }^{45} \mathrm{Az}$ eredeti rajz szerint a torony inkább patkó alakú és nem félköríves. A falból tömegesen elókerült római kőemlékek, a torony viszonylag csekély mélysége (itt a rajz szerint a fal teteje már 1,17 m mélységben jelentkezett, míg máshol az átlagos mélysége a római rétegeknek 3,2-4 m (bár a terepalakulat Duna fele való lejtését is figyelembe kell venni)) jogossá teszi azt a feltételezést, hogy a Kuzsinszky által megfigyelt objektum valójában nem római kori, hanem Pest középkori városfalának része. ${ }^{46}$ Ezt XVII-XVIII. sz-i metszetek alapján is feltételezhetjük, mivel a nagyobb rondellákon kívül kisebb félköríves tornyokat is ábrázoltak. ${ }^{46 a}$ Márcsak amiatt is jogos a feltételezés, mivel korábban a Régiposta utcai rondellát azért tartották római eredetúnek, mert itt is nagyobb mennyiségú többszörösen felhasznált római faragott kőemléket találtak. ${ }^{47} \mathrm{~A}$ következtetés logikus is, mivel aligha feltételezhetó, hogy akár III. sz.-i erődfalakba is tömegesen építsenek be kőemlékeket (különösen nem III. századiakat) ${ }^{48}$ Nagy L. megfigyelése szerint a toronyból származó kőemlékek római habarcsosak. ${ }^{49}$ Ez sem zárja azonban ki a torony középkori eredetét, mivel középkori falhoz felhasznált kôemlékek a helyi római erôd falából is származhatnak, és nem valószínú, hogy a középkorban a római habarcsréteg eltávolításával foglalkoztak volna. Az előkerült téglabélyegek egy része a III. századból származik (cohors VII Breucorum Ant., Exercitus Pannoniae Inferioris), ezek azonban a középkori sírok mellett kerültek elô szórványként olyan területen, ahol római objektum nem volt megfigyelhetô. ${ }^{50}$ Ezen téglabélyegek nem keltezhetik a IV. századinál nagyobb korai erődöt. Legkorábban valószínúleg őrtorony-hídfóállás épülhetett a környéken, majd ezt követhette az első nagyobb építkezés. Ebból a szempontból igen fontos, hogy a tábor belsejében húzott kutatóárkok negatív eredményt hoztak, azaz a korábbi erôd belső épületeit is a falak mellé építhették. Ez egy a korai ellenerőd esetében, mint pl. az idézett leányvári esetében, kizárható. Mindezek alapján az alig ismert korábbi erôd valamikor a két időpont (Caracalla-II. Constantius) között épülhetett. Így az ismert régészeti adatok nem mondanak ellen Hydatius Acincumjának Aquincummal való azonosításának, ezért azok az azonosítás során nem lehetnek kizáró indokok.

${ }^{45}$ Nagy: i. m. (12. j.) $10-15$.

${ }^{46}$ A középkori városfalakhoz: Rómer F: A régi Pest. Budapest 1873. 153-165; Írásné Melis K.: A pesti késóközépkori városfal kutatása - Archäologischen Daten zur Erforschung der spätmittelalterlichen Stadtmauer von Pest. ArchÉrt 114-115 (1987-1988) 199-225. A római és középkori falak kapcsolatáról: Bóna I.: Az Árpádok korai várai. Debrecen 1998. 56-58, 104, 89-91. képek.

${ }^{46 a}$ Pl. Nagy: i. m. (12. j.) 1., 70., 71., 72. képek. A Duna parti — később lebontott fal — ábrázolása: BTM ltsz. 15725 (Papp-Váry Á-Hrenkó P.: Magyarország régi térképeken. Budapest 1990. 80-81), Rómer: i. m. (46. j.) 108, 155.

${ }^{47}$ Nagy: i. m. (12. j.) 10.

${ }^{48}$ A faragványok egy része a III. sz. közepére is keltezhető: Nagy: i. m. (12. j.) 18.

${ }^{49}$ Nagy L.: Pest város eredete. Tanulmányok Budapest múltjából 3 (1934) 13.

${ }^{50}$ Nagy: i. m. (12. j.) 72-73. Ez alól kivétel a Szirmai K. által talált coh. VII Br. Ant. téglabélyeg, amely egy planírozási rétegben került elő. A legio II adiutrix itteni téglabélyegei későbbiek: $B$. Lớrincz: Pannonische Ziegelstempel II. Limes-Strecke Vetus Salina-Intercisa. DissArch II, 7. Budapest 1978. 1117, 26, 43, 145, Anm. 99. 
III. Az elôzőekhez képest sokkal problematikusabbnak túnnek számomra a szerző Trans előtagú helynevekre vonatkozó fejtegetései.

1. A Trans kezdetû́ helynevek általában valóban területi egységekre vonatkoznak, de nem a IV-V. századi forrásainkban, főleg nem a Notitia Dignitatumban találhatók. Semmilyen bizonyítékunk sincs arra nézve, hogy a katonai sematizmus katonai csapattesteket és azok erődjeit felsoroló listák közé felügyelt területeket is beillesztettek volna. Az a feltételezés sem állja meg a helyét, hogy Trans előtagú helyneveket ne ismernénk a Notitián kívül máshonnan a római birodalomból: pl. pagus Translucanus (CIL II 1041), Transalium vicus (Greg. Tur. de virt. b. Martini 2, 10, lib. vit. pat. 13, 3), ${ }^{51}$ mutatio Trans monte (It. Burd. 574, 6), Translitis (It. Burd. $566,9)$. Az ilyen helynevek ritka elófordulása nem arra bizonyíték, hogy ez nem helynév, hiszen akkor a hasonló ritkaságú Contra előtagos neveink sem lehetnének helynevekként értelmezhetôk. Nem feltétlenül ellentmondás Transdrobeta esetében a fennmaradt Pontes név, hiszen a contra elótagos nevek esetében előforduló más

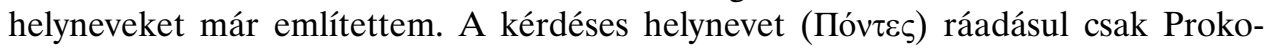
piostól (De aed. IV, 6, 8-18) ismerjük, Cassius Dio (LXVIII, 13, 1-6) helynevet nem említett, Traianus hadjáratának tárgyalása során csak leírta a híd építését.

2. Nem mond ellen a római földrajzi felfogásnak a trans szó használata Dacia Ripensis erődjeire, vagy ha ellentmond, akkor a kérdéses helyneveket Duna jobb parti területekre sem lehet vonatkoztatni.

3. Aligha felel meg a valóságnak a Transmarisca szó etimologizáló magyarázata (nem Trans elótag+helynév). A terület antik nyelveinek kutatói közül ez eddig senkiben sem merül fel. A helynév leginkább a trákból vezethetô le, a szó az idg. mer(i)sk-mocsár szóból származtatható, amelyet trans előtaggal láttak el. Tra $(n) s$ kezdetú, marisca utótagú trák szó, vagy ehhez hasonló, nincs. ${ }^{52}$ Transmariscát a Tabula Peutingeriana is ábrázolja, ezért mindenképpen egy erőd nevéről van szó, amelyben maga Diocletianus is tartózkodott éppen 294-ben (Cod. Iust. VI, 42, 28).

4. Trans elôtaggal ellátott helynév melletti Contra előtagos csak Aquincum esetében figyelhetô meg. Így a felsorolt katonai egységeknek állomásozniuk kellett valahol. Így van ez pl. Transalba, Transluco, Transmarisca, Transdiana ${ }^{53}$ (?) esetében (Not. Dig. Or. XL, 23, XLII, 23, 27). Ennek pedig a legvalószínúbb helye egy-egy Trans előtagos helynevú erőd lehetett. Így jogos M. Zahariade feltételezése, hogy Translucus Hajdućka Vodenicával azonosítható, amely Lucusszal (ma Ogradena) szemközt terült el a Duna jobb partján..$^{54}$

5. Nem látom szükségszerúnek, hogy minden esetben egy-egy katonai tábor körüli területnek - akár a Barbaricumban is - ne lehetett volna ugyanaz a neve,

${ }^{51}$ A. Holder: Alt-Celtischer Sprachschatz II. Leipzig 1900. 1904.

52 D. Detschew: Die thrakischen Sprachreste. Wien 1957. 520; A. Holder: Alt-Celtischer Sprachschatz II. Leipzig 1900. 1904.

${ }^{53}$ V. Kondic: Transdiana. Starinar 43-44 (1992-1993) 49-52.

${ }^{54}$ M. Zahariade: A note on Translucus (NDOr XLII, 27). Starinar 47 (1996) 249-251. 
mint a tábornak. Ennek éppen az ellenkezőjére vannak példáink (pl. Castellum Veluniate (AÉp 1958, 105), Castellum Abritanorum (CIL V 942), valamint az alsópannoniai Castellum Vixillum (CIL VI 2544=ILS 2066)), amikor az erôd neve válik helynévvé és a mellette fekvô auxiliaris vicus territoriumára is vonatkozik. Ezen analógia alapján válik csak jogossá a szerző fejtegetése a területi egység nevére. Ugyanezen elv alapján egy város nevét addig használják egy-egy adott területre vonatkozóan, amíg az adott város territoriuma tart. Egy-egy városi origo feliraton való feltüntetése nem csak azt jelenheti, hogy az elhunyt magában a városban született, hanem annak territoriumára is vonatkozhat. Sokszor megfigyelhető, hogy az origot város-pagus-vicus rendszerben adták meg (pl. CIL VI 3297, 32713). Ezekben az esetekben nem takarékoskodtak a feliraton a hellyel és a szöveggel, míg másoknál igen. Ekkor csak a városnak, általában mint területi egységnek a nevét adták meg, amelyhez tartozó településen született az egyén (pl. Aquincum esetében: CIL VI 3431, 3454, 31234, 32536, 32624, 37208). Különösen igaz ez olyan bennszülöttek esetében, akik a törzsi hovátartozásukat is megjelölik, mint natiojukat: pl. cives Cotini domo Mursa: CIL VI 32542. Ennek a folyamatnak az ellentettje is ismert, amikor egy területi egység neve átment az ott épült erődre is: Pl. Aureus Mons helynevek (Not. Dig. Or. XLI, 6=15, 28, Oc. XXXII, 45), de ebben az esetben is helynévról van csak szó.

6. Véleményem szerint földrajzi megoszlásuk szempontjából is további vizsgálatra szorulnak a Notitita Trans és Contra előtagos, igen ritka (6, illetve 8 eset) helynevei (Not. Dig. (ed. Seeck) p. 285, 299). Feltúnő, hogy a Trans-os helynevek csak az alsó-dunai provinciákban (leginkább Dacia Ripensisben) és Valeriában találhatók meg, míg a Contra előtagosak szinte csak Valeriában (egy-egy moesiai és osrhoenei kivétellel), valamint Thebaisban. Az It. Ant. Contra előtagos helynevei mind területi eloszlásukban, mind gyakoriságukban gyakorlatilag megegyeznek a katonai sematizmuséival. Ilyen helyneveket egy belgicai kivétellel (Contra Aginnum-It. Ant. 379, ${ }^{55}$ ) azonban csak Aegyptusból ismer, összesen 9-et (It. Ant. 159, 3, 160, 4-5, 161, 1, 164, 2-4, 165, 2-3). Utóbbiak valóban Nílus túlparti helységek. ${ }^{56}$ Ezek közül a számunkra legfontosabb Contra Apollonopolis esete, amely a Nílus jobb partján feküdt, nem pontosan szemközt Apollonopolisszal. ${ }^{57}$ Úgy túnik, hogy ennek a területi megoszlásnak fontos szerepe volt az erődök Trans vagy Contra elótagos elnevezésében. Így mindössze csak arról volt szó, hogy Pannoniában és Aegyptusban inkább a Contra, Daciában a Trans előtagot használták a túlparti erődök meghatározá-

55 A helység a Notitiából is ismert (Occ. 42 41), azonban kérdéses, hol volt Aginnum, mivel az Itinerariumból ismert azonos nevú helység $(461,7,462,4)$ csak Aquitaniából ismert a Burdigala-Tolosa úton, ma Agen, Contra Aginnum pedig a Tarvenna-Durocortorum úton helyezkedett el, ma Avigny: $K$. Miller: Itineraria Romana. Römische Reisewege an der Hand der Tabula Peutingeriana. Stuttgart 1916. $63,107,121$.

${ }^{56}$ Der Kleine Pauly I. Stuttgart 1967. 1297.

${ }^{57}$ K. Miller: i. m. 861. 
sára. Egyedi Aquincum esete, ahol két túlparti erősséget is el kellett a rómaiaknak nevezni, ezért kényszerültek a Trans helynév használatára is.

7. A felsőgödi tábor Dunától való távolsága $(\mathrm{kb} 3 \mathrm{~km})$ nem lehet ellenérve a Contra Constantiamra való emendálásnak, ${ }^{58}$ mivel a Conradculia/Conradcuha $=$ Contra Herculia $=$ Szob $^{59}$ helynév (Not. Dig. Occ. XXXIII, 6, 27- már O. Seeck is csak a Contra Herculia emendatiot tartotta elfogadhatónak — Not. Dig. (ed. Seeck) p. 193, 285) esetében az eredeti pilismaróti tábor, Ad Herculem is kb 2 km távolságra van a Dunától. ${ }^{60}$ Továbbá ebben az esetben a titeli feltételezett erốd sem lehet contra-erőd, mivel Acumincumtól való távolsága légvonalban több, mint $8 \mathrm{~km}$ (a mocsarak miatt a valóságban ennél jóval több).

8. Nem teljesen érthető a szerzőnek a két praepositio (trans-contra) közötti különbségtétele. Ennek ebben a korban (Kr. u. IV. sz.) csekély jelentésbeli különbsége lehetett, amelyet éppen a Notitia Contra Aquincumra vonatkozó bejegyzése mutat világosan. A bejegyzés szerint az auxilia vigilum Contra Acinco tras in barbarico állomásozott (a trans elöljárószó jelen, határozói használatának esetében véleményem szerint indokolatlan a Böck-féle konjektúra). A trans praepositionak, mint mindegyik másiknak, sokféle jelentése lehetett. Így igék mellett, a hol kérdésre felelően, jelentése lehetett „túloldalon” vagy „másik oldalon”. A Trans előtagú helynevek későrómai korban való használatának nyelvészeti szempontból is nagy fontossága van, mivel az újlatin nyelvekben az amúgyis viszonylag ritkán használt praepositio az intra-val való hasonlósága (amely tra-ra változott) miatt visszaszorult, helyette gyakran az ultra és supra praepositiokat használták „mögött”, illetve „keresztül” értelemben ${ }^{61}$ Talán témánkba vág egy Caesar-hely (B. C. $3,13,6$ ): trans flumen ... positis castris. A római helynévadás gyakorlatának megfelelóen így Castra trans ... (posita) is lehetett egy tábor neve.

9. A fejtegetések azon praemissából indulnak ki, hogy a Gellérthegy római kori neve mons Teutanus lett volna. Az erre vonatkozó adatok kiindulópontja, hogy a bölcskei oltárköveket innen hurcolták el ${ }^{62}$ és a Rezeda utcai Teutanus-oltárkô, amely az első híradások szerint in situ került elő (CIL III 10418). ${ }^{63}$ A szomszédos telken folyt kontrollásatás azonban az in situ, római kori lelőhelyen való elókerülést nem

${ }^{58}$ Soproni: i. m. (11. j.) 79-81, 171-172.

${ }_{59}$ Magyarország régészeti topográfiája 9. Budapest 1993. 328-329, 26/28. lh.

${ }^{60}$ Soproni: i. m. (11. j.) 46-48.

${ }^{61}$ M. Leumann-J. B. Hoffmann-A. Szantyr: Lateinische Grammatik II. München 19775. 251252; R. Kühner-C. Stegmann: Ausführliche Grammatik der lateinischen Sprache. Hannover 1976 ${ }^{5}$. 546; W. M. Meyer-L. Lübke: Grammatik der romanischen Sprache III. Leipzig 1902. Nr. 447; Ch. T. LewisCh. Short: A Latin dictionary. Oxford 1879. 1887-1888.

${ }^{62}$ S. Soproni: Előzetes jelentés a bölcskei későrómai erőd kutatásáról - Vorläufiger Bericht über die Erforschung der spätrömischen Gegenfestung in Bölcske. CommArchHung (1990) 133-142; id.: CIL III 10481. BudRég 30 (1993) 177-183.

${ }^{63}$ Fröhlich R.: Aquincumnak római feliratai. BudRég 3 (1891) 147; Hampel J., Az eraviscusok földje és fôvárosa. BudRég 4 (1892) 52-53. 
erősítette meg. ${ }^{64}$ Még a legújabb feltárások során még jóindulattal is csak szórványosnak nevezhető római leletanyag került elő a lelóhelyről. ${ }^{65} \mathrm{~A}$ Citadella építésekor — stratégiai fontossága ezt indokolja is - római ôrtornyot semmisíthettek meg. ${ }^{66}$ Aquincum területén a Szépvölgyi úti villa szentélyéből azonban in situ ismerünk egy Teutanus-oszlopot (AÉp 1965, 349), ${ }^{67}$ így az azonosítás ellen jogosan emelt kifogásokat legutóbb Póczy K. ${ }^{68}$ Ezek alapján további alaposabb bizonyításra szorul a szentélykörzet hollétének kérdése.

Fenti fejtegetéseim alapján a Trans kezdetú helynevek ugyanúgy vonatkozhattak túlparti erődökre. Így Aquincum esetében, amennyiben elfogadjuk az egyébként is igen bizonytalan Contra Tautantum azonosítást, akkor még egy nagyobb balparti erődöt kellene Budapest környékén keresnünk. Ilyet azonban legközelebb csak Felsőgöd és Dunaharaszti térségében ismerünk.

Mindezekból a következó következtetések vonhatók le Hydatius adatára vonatkozóan:

1. Nem bizonyítható, sốt indokolatlan Hydatius Acincum helynevének Acumincumra való emendatiója. Ugyanez vonatkozik a Notitia feltételezett tévedésére is. Nincs arra vonatkozó biztos adatunk, hogy az antik szerzők valaha is keverték volna a két helynevet. Ezzel ellentétben: 1. Ismert az Aquincum helynév Acincum változata. 2. Not. Dig. Contra Acincum helyneve csak Aquincumra vonatkozhat. 3. Az in barbarico és az in Sarmatia kitétel is csak Aquincumra vonatkozhat. 4. Hydatius Fastijában is előfordul az Acincum=Aquincum névváltozat. Ezek alapján nem az Aquincummal való azonosítást kell bizonyítani, hanem ennek ellenkezőjét.

2. Titel esetében máig nem nyert bizonyítást egy ellenerőd léte, sốt eddigi adataink ennek ellentmondani látszanak. Régészeti adataink nem mondanak ellen az Eskü téri erőd 1. periódusa tetrarchia-korra való keltezésének.

3. A Notitia Trans- kezdetú helynevei nagy valószínúséggel csak katonai táborokra és nem területekre vonatkoznak.

4. Jobb híján Soproni S. emendatioja fogható fel a legjobb megoldásnak a romlott Contra Tautantum helynév azonosítására (=Contra Constantia).

${ }^{64}$ Alföldi A.: Epigraphica II. ArchÉrt 52 (1939) 108-109; Csemegi J.: A Gellérthegy déli oldalán oltárkő helyének meghatározása. FolArch 3-4 (1941) 319-325; Nagy T:: A Fóvárosi Régészeti és Ásatási Intézet jelentése az 1938-1942. évek között végzett kutatásokról. BudRég 13 (1943) 367.

${ }_{65}$ Petó M.: Gellérthegy. Budapest 1997. 15-29.

${ }^{66}$ Radnóti A.: Buda régészeti emlékei. Magyarország múemléki topográfiája IV. Budapest 1955. 29. A Citadella építéséról szóló rövid katonai jelentésben nem esik szó az előkerült római leletekrôl (Petó: i. m. 27. T. 26), ahogyan a százhalombattai római tábor területén 1809-ben megépített hídfőállásról szóló hosszabb jelentés sem számol be a római és középkori emlékek szétveréséról: Kovács P.: Vicus és castellum kapcsolata az alsó-pannoniai limes mentén. Piliscsaba 1999.61.

${ }^{67}$ T. Nagy: Quelques aspects de la romanisation dans la Pannonie orientale. in: Huitième congrès international d'Archéologie Classique. Paris 1965. 375-381.

${ }^{68}$ Póczy K: Iuppiter Optimus Maximus Teutanus Aquincumban. in: Pannoniai kutatások. A Soproni Sándor emlékkonferencia előadásai, Bölcske, 1998 október 7. Szekszárd 1999. 201-223. A témakörrel máshol foglalkozom részletesen. 
A két valószínúsíthetôen diocletianusi alapítású dél-pannoniai erôd, Rakovac és Čortanovci közül csak az utóbbi ismert jobban. ${ }^{69} \mathrm{~A}$ tetrarchia-kori keltezést a két, tetrarchákra visszavezethető tábornév támogatja: Ad Herculem, Castra Herculis ${ }^{70}$ bár a névadás önmagában nem lehet elegendô bizonyíték. ${ }^{71}$ Több feltárás is folyt a mintegy $70 \times 100 \mathrm{~m}$ kiterjedésú Čortanovci táborában, amelynek során az egyik háromnegyed kör alakú saroktornyot teljes egészében feltárták. ${ }^{72} \mathrm{Az}$ ásatók is a III. sz. végi-IV. sz. eleji keltezést fogadták el. A saroktorony nem a IV. századi Pannoniában is elterjedt toronytípushoz tartozik..$^{73}$ A saroktorony melletti oldalon egy négyzetes kiugró torony is előkerült, amely oldal-, de kaputoronyként is azonosítható. ${ }^{74}$ Utóbbi mellett az szól, hogy a torony egy kisebb erôdnek (nagyjából) a közepén helyezkedik el, ezért logikus lehet kaputoronynak tartani a feltárt falrészeket. Ez azonban nem lehet döntő érv, mivel a torony a saroktoronytól $\mathrm{kb} 30 \mathrm{~m}$ távolságra helyezkedik el, amennyiben tábor kapuzatához tartozó toronyról volna szó, az nem a tábor mértani közepén volna található. A másik ellenérv, hogy ebben az esetben nem a frons praetoria oldalán (jelen esetben Duna felóli) volna a tábor kapuzata, mint a késôrómai táborok esetében az szokásos. Ezért az elôkerült tornyot inkább oldaltoronynak lehet tartani. Így a tábor egy-egy hosszanti oldalán két-két kiugró oldaltoronnyal számolhatunk, mint pl. az Eskü téri erőd esetében. Ez azért is fontos, mivel a háromnegyed kör alakú saroktorony, illetve kiugró négyzetes oldaltoronytípus kombinációja a III. sz. második felében fordul eló. Így a Litus Saxonicum erődjei közül a 286 előttre keltezhetô richboroughi erődnek voltak hasonló tornyai. ${ }^{75}$ Hasonló toronytípust azonban Syriából is ismerünk, ahol a hasonló nagyságú és valószínúleg szintén tetrarchia-kori sa'nehi erődnek voltak ilyen tornyai. ${ }^{76}$ A két pannoniai tábor alapítása a Pannonia Inferior kettéosztása után a legiok nélkül maradt Pannonia II számára létrehozott legio V Iovia és legio VI Herculia létrehozásával hozható kapcsolatba. ${ }^{77}$

A tetrarchia-kori átépítésekre epigráfiai adatunk is van Pannoniából. A legio VI Herculia által Galerius számára 306-8 körül emelt felirat bizonyítja a legio kis-

${ }^{69}$ TIR L 34. Budapest 1968. 49-50, 95; A. Alföldi: Der Untergang der Römerherrschaft in Pannonien I. Leipzig 1924, 24-25; VHAD (1910-1911) 105, 108; Rakovać: Arheološki nalazi. Novi Sad 1982.

70 Soproni: i. m. (11. j.) 128-129.

${ }^{71}$ Tóth E.: Tetrarchia-kori Iovia-Herculia helynévadás Pannoniában? - Tetrarchiezeitliche Namengebung von Iovia-Herculia in Pannonien? ArchÉrt 109 (1982) 57.

${ }^{72}$ M. Manojlović: Rimsko utvrdenje kod Čortanovaca — Eine römische Befestigung bei Čortanovci. Rad Vojvodanskih Muzeja 11 (1962) 123-125.

73 Tóth: i. m. (1. j.) 125-126.

${ }^{74}$ V. Dautova-Ruševljan: Rimsko utvrdenje kod Čortanovaca-Roman fortification near Čortanovci. Rad Vojvodanskih Muzeja 36 (1994) 13-33, 14.

75 S. Johnson: The Roman forts of the Saxon shore. Southampton 1976. 51; J. S. Johnson: The date of the construction of the Saxon shore fort at Richborough. Britannia 1 (1970) 240-248; V. A. Maxfield (ed.): The Saxon shore. A handbook. Exeter 1989. 143-145.

${ }^{76}$ D. Kennedy-D. Riley: Rome's desert frontier from the air. London 1990. 189.

${ }^{77}$ E. Ritterling: Legio. in. PWRE XII. Stuttgart 1925. 1355; Soproni: i. m. (11. j.) 128-129. 
kőszegi (Ad Militare) állomásozását. ${ }^{78}$ Ennél valamivel korábbra tehetjük a többek által is feltételezett késő római erőd megépítését megváltoztatott helyen. ${ }^{79} \mathrm{Az}$ új legio felállítása, valamint itteni állomásoztatása szükségszerúvé is tette a korábbi auxiliaris erőd átalakítását. A tábor tetrarchia-kori átépítését egy közöletlen építési felirat teszi bizonyossá. ${ }^{80}$ Ugyancsak a legio kiskőszegi állomásozását bizonyítják az itt elôkerült téglabélyegek. ${ }^{81} \mathrm{~A}$ már régóta ismert lelóhelyen régészeti feltárás még nem volt. A múlt században Rómer F. mérte fel a lelóhelyet és készített róla alaprajzot (Rómer F. jgyk., OMF Irattár XX, 103-106). A XVIII. századi térképek, illetve a felszíni nyomok alapján Bulat szerint a vár (grad) helyén állhatott a késô római erôd, a korábbi auxiliaris tábor pedig a jelenlegi felszabadulási emlékmú helyénél egy valamennyivel alacsonyabb magaslaton. A Rómer-féle helyszínrajzon jól látható a késốrómai tábor terepalakulatokat követő szabálytalan formája. Oldaltornyait azonban nem ismerjük.

További építkezésekkel is számonunk kell és lehet főleg a déli limesszakaszon a tetrarchia korában, mivel a ezen a részen a késô római korban a korábbi auxiliaris erődök száma megnőtt és ezt még a két új legio itteni állomásozása is fokozta. A korábbi erődök (Ad Militare, Teutoburgium, Cornacum, Malata-Bononia, Acumincum, Rittium, Burgenae, Taurunum) mellett a Not. Dig. alapján katonai csapatok állomásoztak Aureus Mons, Ad Novas-Vörösmart, Albanum-Laskó, Cusum-Pétervárad, Cuccium-Ilok, erődjeiben (Occ. XXXII, 25, 28-29, 32, 34, 40, 45) ${ }^{82}$ Mindezek építésének korát keltező adatok hiányában egyelőre nem ismerjük. Aureus Mons valószínúleg a tetrarchia-korban épült, mivel itt a legio VI Herculia egyik részlege állomásozott. Az erőd valószínúleg a Dráva és a Duna háromszögben keresendő (Kő?). ${ }^{83}$

${ }^{78}$ T. Nagy: Zu den Militär- und Verwaltungsreformen Diokletians. in: Akte des IV. Internationalen Kongresses für griechische und lateinische Epigraphik, Wien 1962. Wien 1964. 274-280= ILJ 1072 .

${ }^{79}$ M. Bulat: Topografska istrazivanja limesu u Slavoniji i Baranji-Topografische Limesforschungen in Slawonien und in der Baranja. Osjeckije Zbornik 12 (1969) 39-52, 40-41, 50; D. Pinterović: Problemi u istrazivanju Limesu na sektoru Batina Skela-Ilok. Osjeckije Zbornik 12 (1969) 53-69. 57-58, 76; Pósta B.: Baranya az ôskortól a honfoglalásig. in: Baranya múltja és jelenje II. Szerk.: Várady F. Pécs 1897. 5-208, 88-90, 186-87, VISY 1989, 121

${ }^{80}$ Nagy: i. m. (78. j.) $278=$ ILJ 1073.

${ }^{81}$ J. Szilágyi: Inscriptiones tegularum Pannonicarum. DissPann II. 1. Budapest 1933. 42.

82 TIR L 34. Budapest 1968. 25, 26, 41, 51; Bulat: i. m.; Pinterović: i. m.; Soproni: i. m. (11. j.) 136, Anm. 137.

${ }^{83}$ A. Graf: Übersicht der antiken Geographie von Pannonien. DissPann. I. 5. Budapest 1936. 112; TIR L 34. Budapest 1968. 31. 


\section{Félköríves oldaltornyok Pannoniában?}

Pannonia Inferior régóta legjobban ismert erődjei közé sorolják a szentendrei auxiliaris castellumot. ${ }^{84}$ A II. sz. elején épített, $205 \times 134$ m kiterjedésú, trapézalakú kőtábornak palánkperiódusa még nem ismert. ${ }^{85} \mathrm{~A}$ belsố épületek közül a principiát tárták fel teljes egészében. Ezen kívül még két nagyobb épületet tártak fel részlegesen a retenturában és egy kisebbet a porta principalis dextra közelében. A védmúvek eddigi kutatása során feltárták két saroktornyát (trapéz- és legyezőalakúak), három kapuját (porta praetoria, decumana és principalis dextra), egy-egy beugró, illetve kiugró oldaltornyát. Az oldaltornyok periódusai közül a beugró, négyszögletes, illetve a késố római patkóalakú oldatornyok váltak ismertté.

A tábor 1939. évi feltárásakor került sor az egyik északi kiugró oldaltornyának a feltárására (1-2. képek). A torony az ÉNy-i sarokhoz legközelebb esô torony (Nagy 1942, 263-267, 2-3 kép, T. XLIV/2). ${ }^{86}$ A későbbi publikációkban az ásatási eredményeket figyelmen kívül hagyva csak a legkésőbbi patkóalakú torony vált ismertté. A $6,5 \times 5,8 \mathrm{~m}$ belterületú torony alatt ugyanis két másik építési periódus figyelhetố meg, amelyet az ásató, Nagy T. is észlelt, a jelenségekról külön tanulmányban készült beszámolni. Legkésőbbre keltezhetố a patkóalakú torony A fala mellett, a torony belsejében a táborfalra szintén merólegesen futó legalább 1,6 m széles fal, amelyre a késóbbi toronyfalat alapozták. Alapozása $40 \mathrm{~cm}$-rel mélyebb, 3,58 m mély, mint a patkóalakú toronyfalé. Az ásató szerint ehhez tartozik a torony belsejében megfigyelt ghi pontok közötti habarcsos padlószint, mivel felsô szintjük között $4 \mathrm{~cm}$ különbség volt csak, továbbá a vizsgált helyen összeépültek. A fal bizonyosan nem lehet a patkóalakú torony alapozási kiugrása, mivel a tornyon kívül az csak $8 \mathrm{~cm}$ széles, míg belül a másik $\mathrm{B}$ falnál megfigyelhetố volt jóval kisebb szélességben. A fal minden bizonnyal a legkorábbi kiugró, négyzetes alakú oldaltorony része. A többi fala valószínúleg a későbbi toronyfalak alapozásául szolgált.

${ }^{84}$ A szentendrei ásatásokról, illetve a táborról: Nagy L.: A szír és kisázsiai vonatkozású emlékek a Duna középső folyása mentében. ArchÉrt 52 (1939) 115-147; Nagy T.: Kutatások Ulcisia Castra területén. ArchÉrt (1942) 261—279; Nagy T.: A Fővárosi Régészeti és Ásatási Intézet jelentése az 1938-1942. évek között végzett kutatásokról. BudRég 13 (1943) 359-399; Nagy T.: Ulcisia castra. BudRég 23 (1973) 39-57; Soproni: i. m. (11. j.) 68-71; S. Soproni: Die Caesarwürde Caracallas und die syrische Kohorte von Szentendre. Alba Regia 18 (1980) 39-51; Magyarország régészeti topográfiája 7. Budai és szentendrei járás. Budapest 1986. 248—255, 28/1 lh.; Soproni S.: Szentendre a rómaiak korában. Szentendre 1987. A feltárások a táborban legutóbbi időkben újra indultak: Maróti É.: Ulcisia Castra római tábora - a kutatás előzményei és jelenlegi állása. in: Kutatások Pest megyében. Tudományos konferencia I. Szentendre 1997. 354-360

85 Valószínúleg a Dunához közelebb lehetett: D. Gabler: The Flavian limes in the Danube-bend. CommArchHung (1999) 81.

${ }^{86} \mathrm{Az}$ ásatási eredményeket az elôzetes jelentés leírása, illetve a rajzok alapján ismertetem. Természetesen az eredmények hitelesítése szükséges volna, de ennek hiányában mégis szükséges a módosított ásatási eredmények közzététele. 


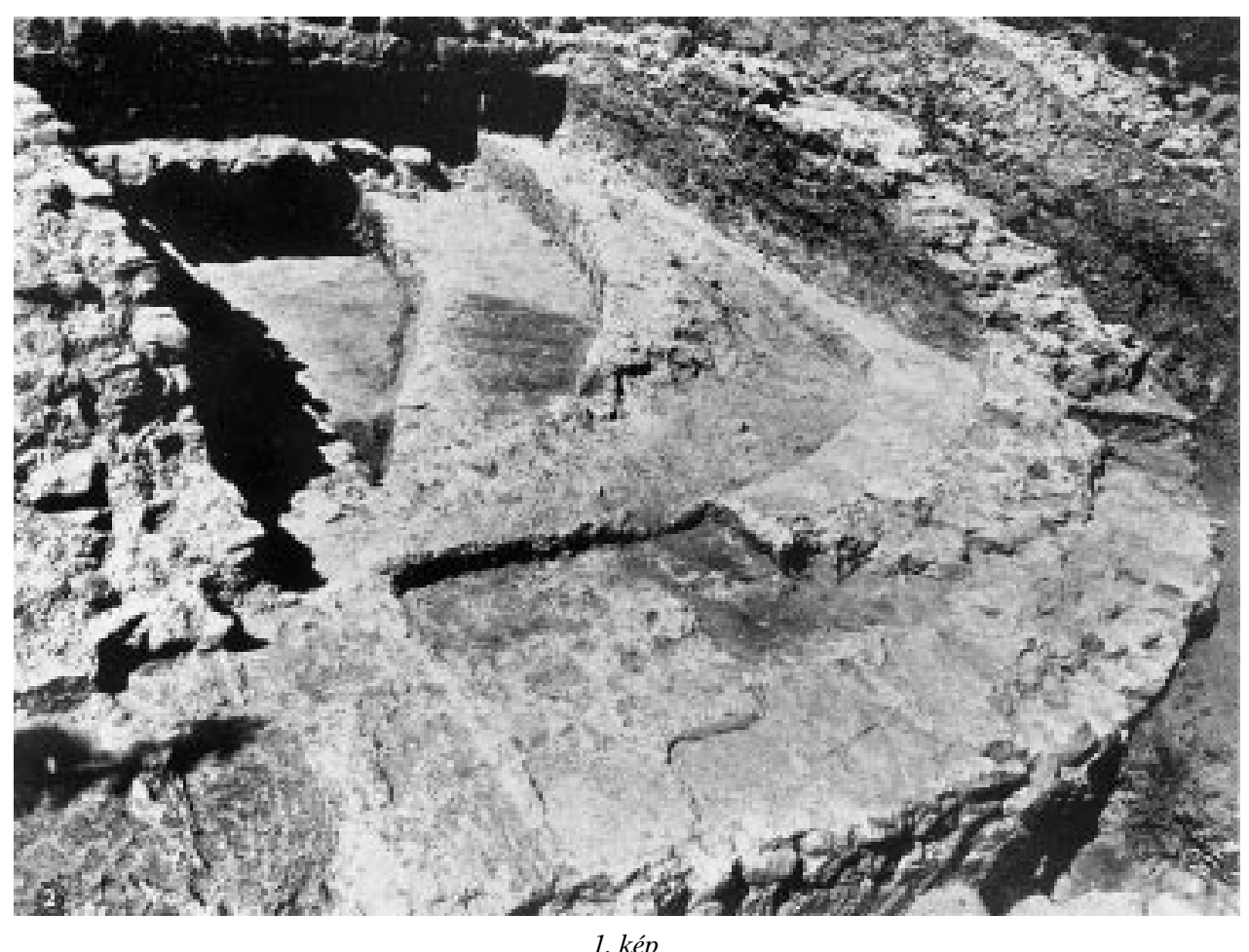

Az elsô periódus belsố padlószintjét a B falnál egy azonos vastagságú, meg nem munkált kövekből kiképzett, habarcsba rakott félkörívalakú falszakasz vágta át (ekf). A fal eredeti szélessége nem ismert, mivel Nagy szerint a B fal és k fal közötti részt (ez főleg a $\mathrm{BC}$ falak találkozásánál levő részt jelenti) egy habarcsleöntés töltötte ki. Alapozása a legmélyebb, 3,96 m, amelyhez mészbe rakott szabálytalan köveket használtak fel. Ennek a toronynak a hátsó fala lehetett a Nagy T. által feltárt, a táborfal belsố oldalához hozzáépítetett $\mathrm{A}$ fal ${ }^{87} \mathrm{Az} 1,4-1,17 \mathrm{~m}$ széles $\mathrm{K}-\mathrm{Ny}$ irányú, nagy kôlapokkal kirakott fal alapozási mélysége csak 1,98 m. A kiásott vége alapján a torony eredeti szélessége 1,4 m lehetett. A félkörívalakú torony belmérete kb $12 \times 6 \mathrm{~m}$ lehetett.

Az ezt követô harmadik periódus a tulajdonképpeni patkóalakú torony. A korábbi falakat erôsen visszabontották, a torony belsejét szabálytalan, a korábbi falak visszabontásából származó kövekkel feltöltötték, majd erre emelték a habarcspadló- 


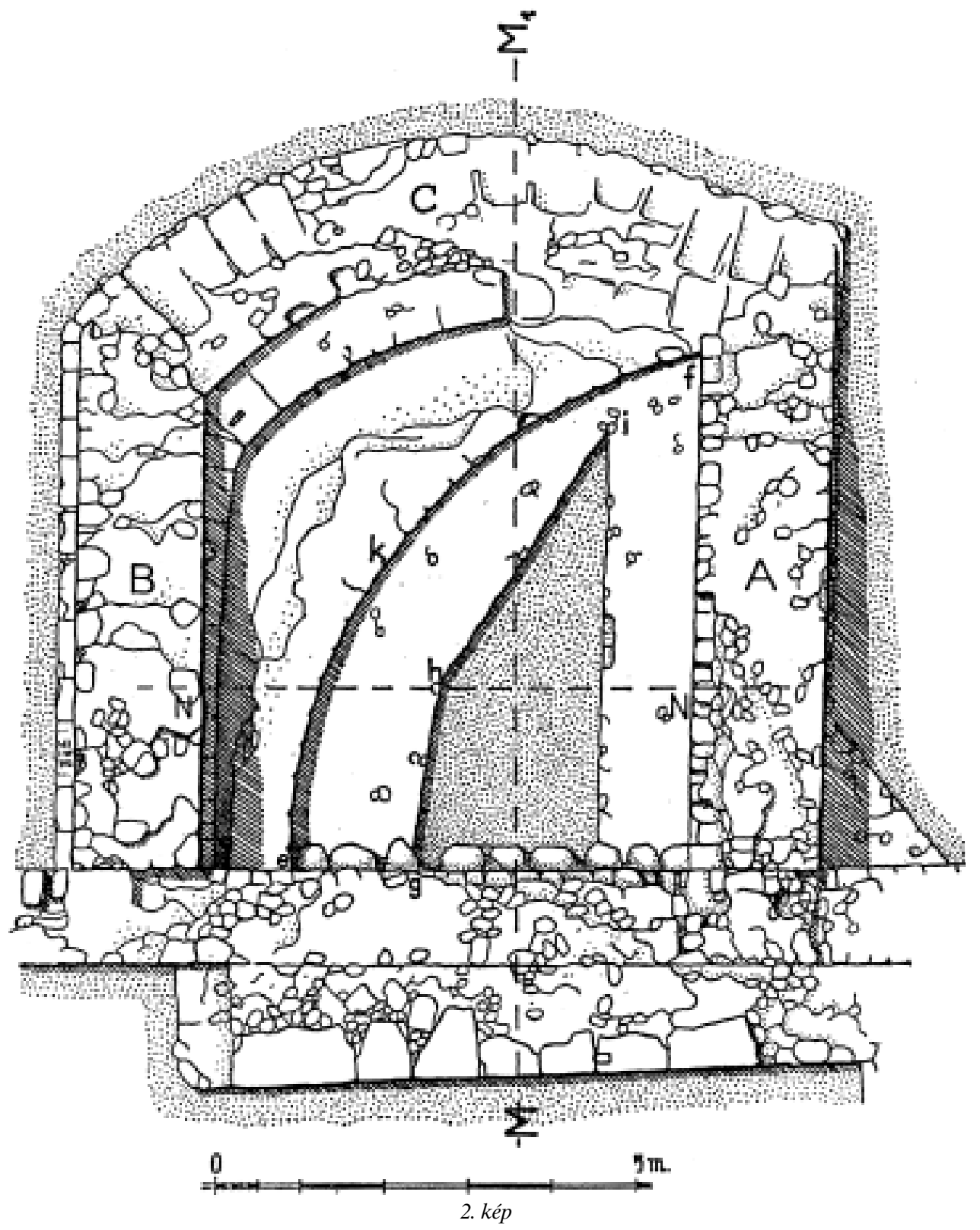


zatot, amely felett egy égési réteget is megfigyelt Nagy T. Ehhez a periódushoz tartozik az A fal tornyon kívül megfigyelt, a toronytól távolodva egyre vékonyodó habarcsos építési szintje. Ez alatt a toronyfallal (A) nagyjából megegyezô, de kissé nagyobb mélységú falkiszedést találtak. Rendeltetése egyelőre ismeretlen, Nagy T. szerint nem lehet támfalról szó, véleményét nem indokolta. Nem megoldott az A fal alatti 2,75 m széles korábbi fal kérdése sem. A korábbi torony, amelyre az A falat alapozták aligha lehetett ekkora szélességú, ezért nem kizárt, hogy az A fal építésekor a korábbi visszabontott fal alapozását megszélesítették. Ezt látszik megerôsíteni az alapozási kiugrástól induló „meszes leöntés”- építési szint. Az égési réteg alatt sárgamázas edénytöredékeket és Quadriburgium téglabélyeget találtak. A felső szinteket a mély beásások zavarták. A bekötó falak - ahova korábbi feliratos és faragott kőemlékeket is beépítettek (RIU 885) - 1,5 m, az íves falszakasz 1,65 m széles. A bekötő falak hosszúsága azonban egymástól erősen eltérô (A- 7,82, B-6,5 $\mathrm{m}$ ), ezért a torony erősen aszimmetrikus. Ennek oka csak az első periódus fala lehet. A tábor szemközti oldalán Nagy L. által feltárt oldaltorony tulajdonképpen a porta principalis dextra elfalazása. ${ }^{88}$

Maga az ásató, Nagy T. is megkülönböztette a kőtábor két (tulajdonképpen három) építési periódusát, lényegében az általunk felvázoltak szerint azonosítva a jelenségeket, a belőlük levonható következtetéseket azonban nem szúrte le. Ulcisia castra építési korszakait figyelembevéve az elsô periódus eredetileg a tábor második oldaltorony-típusa (az elsố a más helyen megépített beugró négyzetes oldaltorony). Eltérô az alapozási mélysége a táborfaléval (utóbbié 3,25 m mély), ezért valószínúleg nem egy korból származnak. A torony a Severus-kor második felére keltezhetô, leginkább Caracalla korára, hiszen nagy számban ismertek a cohors milliaria Surorum Antoniniana feliratos bélyegek a táborból (Nagy: i. m. (84. j.)), továbbá ebből a korszakból való egy építési felirat is (Soproni: i. m. (84. j.)= RIU 840), amelyek alapján nagyméretú átépítések folytak a táborban (pl. principia átépítése). Ennek során kerülhetett sor az oldaltornyok átépítésére is. Kiugró, négyzetes alaprajzú oldaltornyok, ha nem nagy számban is, de ismertek a római birodalomban. Ezek közül korban a legközelebbi a 185 -192 közötti niederbieberi, ${ }^{89}$ valamint a Severuskor alatt megépült Ain-Sinu legiostábora. ${ }^{90}$ A katonacsászárok uralkodása alatt megépített hadidi (valószínúleg Kr. u. 253-259), ${ }^{91}$ de a sacidavai, callatisi és histriai oldaltornyok is viszonylag közel állnak idóben és típusában is a szentendreihez. ${ }^{22}$

Számunkra azonban sokkal fontosabb a következő építési periódus, amelynek során kiugró, félköríves tornyokat építettek hozzá a táborfalhoz. A szokatlanul nagy

${ }^{88}$ Nagy L.: i. m. (84. j.).

${ }^{89}$ E. Ritterling: Das Kastell Niederbieber. BJ 120, 1911, 259—278, 260-63; ORL Abt. B Nr. 1a.

${ }^{90}$ D. Oates, Studies in the Ancient History of Northern Iraq. London 1968. 88-90.

${ }^{91}$ R. E. Brünnow - A. von Domaszewski: Die Provincia Arabia III. Strassburg 1909. 222; M. P. Speidel: The Roman army in Arabia. in: ANRW II. 8, 1978. 724-726.

${ }^{92}$ C. Scorpan: Sacidava - an unusual design and construction method. in: Roman Frontier Studies 1979. Oxford 1980. 787-798. 
méretû́ oldaltornyok miatt az erôd hosszabbik oldalain is csak $2-2$ oldaltorony helyezkedhetett el. Ezt megerősíti a torony távolsága a közelebbi saroktól (63 m), amely alapján a kaputornyokon kívül már csak egy oldaltorony számára van hely. A szokatlanul nagy oldaltorony-típus viszonylag ritka, de egyáltalán nem párhuzam nélküli a Római Birodalom erődépítészetében. A félköríves tornyokkal rendelkezó erôdök közül hasonló méretú volt pl. a kellmünzi $\left(11,6\right.$ m) ${ }^{93}$ sôtt, mint majd látni fogjuk esetlegesen a brigetioi legiostábor oldaltornyai is. Ekkora méretú volt még a tokodi tábor déli nagy oldaltornya is $(13 \times 11 \mathrm{~m}) \cdot{ }^{94}$ Ennél is nagyobb belméretú kerek és poligonális tornyokat ismerünk pl. Oescusból (14,5 m), ${ }^{95}$ Gamzigradból, ${ }^{96}$ Cesavá-ból, ${ }^{97}$ a szintén a tetrarchia alatt épült Castra Martis erôdjéből, ${ }^{98}$ vagy a pannoniai belsố erődök 2. periódusából (pl. Ságvár: 13,7 m). ${ }^{99}$

Régen ismertek a római birodalomban hasonló félköríves kiugró oldaltoronytípusok, amelyek keltezése (a III. sz. 70-es éveitől Valentinianusig) és alakja is eltér egymástól. Félköríves oldaltornyokat elvétve már Augustus korában is építettek pl. Fréjus városfalának esetében. ${ }^{100} \mathrm{Az}$ egymástól eltérô típusok elkülönítésére, időbeli elválasztásukra még csak kísérlet történt. ${ }^{101}$ J. Lander a Constantinus-dinasztia korára tudott elkülöníteni egy csoportot a Rajna vidékén. ${ }^{102}$ Jelen helyen teszünk kísérletet röviden három egymástól erôsen eltérô típus idóbeli megkülönböztetésére. ${ }^{103}$ Formailag három csoportot tudtunk elválasztani, amelyek valószínúleg idóbeli különbséget is takarnak. Az első, a legkorábbi csoportba tartoznak a kiugró, félköríves alakú tornyok, amelyeket a táborfalon belül, a táborfalhoz hozzáépített megerősítéssel láttak el. ${ }^{104}$ Ebbe a csoportba tartozhat a szentendrei is. Ezen tornyok túlnyomó

${ }^{93}$ M. Mackensen: Das Kastell Caelius Mons (Kellmünz an der Iller) - eine tetrarchische Festungsbaumaßnahme in der Provinz Raetien. ArhVest 45 (1994) 145-163, 156, Abb. 12.

${ }_{94}$ A. Mócsy (ed.): Die spätrömische Festung und das Gräberfeld von Tokod. Budapest 1981. 41.

95 T. Ivanov: Das Befestigungssystem der Colonia Ulpia Oescensium. in: Akten des 14. Internationalen Limeskongresses. Wien 1990. 913-923, 918.

${ }_{96}$ D. Srejović-A. Lalović-D. Janković: Gamzigrad. Starinar 31 (1980) 65-80; J. Srejović-C. Vasić: Imperial mausoleum and consecration memorials in Felix Romula (Gamzigrad, East-Serbia). Belgrade 1994.

${ }^{97}$ D. Pribaković: Cesava. in: Stari kulturi u Derdap. Beograd 1969. 88-89.

98 I. Atanassova-Georgieva: Le quadriburgium de la forteresse Castra Martis en Dacia Ripensis. in. Actes de IXe Congrès International d'Études sur les Frontières Romaines. Bucharest 1974. 167-172.

${ }_{99}$ Tóth E.: Az alsóhetényi 4. századi erôd és temető kutatása, 1981-1986. Eredmények és vitás kérdések - Vorbericht über die Ausgrabung der Festung und des Gräberfeldes von Alsóhetény 19811986 - Ergebnisse und Umstrittene Frage. ArchÉrt 114 (1987-1988) 22-61; Tóth E.: Ókeresztény ládikaveretek Ságvárról — Altchristliche Kästchenbeschläge aus Ságvár. FolArch 44 (1995) 107-112.

${ }_{100}$ A. Donadieu: La Pompéi de la Provence. Fréjus 1927; P. A. Février: Fouilles à la Citadelle méridionale de Forum Iulii. Gallia 14 (1956) 35-53.

${ }^{101}$ Lander: i. m. 208-228; H. von Petrikovits: Fortifications in the Northwestern Roman Empire from the third to the fifth centuries A. D. JRS 61 (1971) 178—218, 199.

102 Lander: i. m.231-235.

${ }^{103}$ Igen nehéz és bizonytalan az egyes későrómai erődök keltezése az építési feliratok számának jelentôs csökkenése miatt (cf. Petrikovits: i. m. 178).

104 Természetesen a torony formáját erôsen (de nem alapvetôen) befolyásolja az a tény, hogy egy már meglevó táborfalhoz építik-e hozzá, mint Szentendrén, vagy pedig egy új eróddel együtt építik meg (pl. Burg bei Stein), de a csoportban mindkettő előfordul. 
többsége a III. sz. 70-es éveire, illetve a tetrarchia korára keltezhető. ${ }^{105}$ A második az inkább tetrarchia-kori Constantinus-dinasztia alatti (galliai városok esetében korábbi), Lander által is megkülönböztetett csoport, amelyeknél a félköríves toronyhoz tábor- vagy városfalon belül semmiféle hozzáépítés nem járul. A harmadik csoportba azon Valentinianus (többségében bizonyosan a IV. sz. második feléből) alatti tornyok tartoznak, amelyek a táborfalból kiugróan ugyan kívülról félkörívesnek hatnak, de a táborfalba bekötő falak befelé folytatódnak, így a tornyok valóságosan patkó alakúak. 106

Az elsôbe tartoznak a következô táborok és erôdített városok oldaltornyai (zárójelben a keltezés feltételezett idejével): ${ }^{107}$ Bordeaux (268-70 után), ${ }^{108}$ Beuavais (tetrarchia-k.), Soisson (tetrarchia-k.), Arbon (tetrarchia-k.), Senlis (tetrarchia-k.), Tournai (III. sz. vége), ${ }^{109}$ Carcassone (285 után), Beauvais (Postumus-Diocletianus), Burg bei Stein (294-CIL XIII 5256), ${ }^{110}$ Oberwinterthur? (Kr. u. 294-CIL XIII 5249), Alzey (Constantinus-k. ?), ${ }^{111}$ Horbourg (tetrarchia), Zurzach (III. sz. végeIV. sz. eleje), Alderney (IV. sz. bizonytalan), Yverdon (tetrarchia?), Szentendre (tetrarchia), Pilismarót (késố Constantinus-k.? ld. lejjebb).

A második csoportba a következók tartoznak: Poitiers, St. Bertrand, St. Lizier, Tours, Angers, Saintes (III. sz. 2. fele), Bayonne, Noyon (III. sz. vége-IV. sz. eleje), Orléans (Aurelianus-k.), Sens (Aurelianus-tetrarchia-k.), Dijon (275 után), Bordeaux (268—70 után), ${ }^{112}$ Famars (III. sz. vége—IV. sz. eleje), Vannes (275 után), ${ }^{113}$

${ }^{105}$ Figyelembe kell vennünk azt a feltételezést is, hogy egy-egy típus nem köthető feltétlenül kizárólag egy uralkodóhoz - ilyet mi sem teszünk fel —, de véleményem szerint a későrómai tornyok formája elég jellegzetes egy-egy időszakra (pl. legyező alakú-, illetve patkó alakú tornyok közös használata). A provinciákban alkalmazott típusok között pedig összefüggések - esetlegesen azonos építési program részei - igenis megfigyelhetốk (ezzel ellentétesen: Petrikovits: i. m. 203-204). Elég például felidézni a 370-es évek elejének noricumi-valeriai építkezéseit Ybbs és Visegrád között, ahol jól látható, hogy azonos építési, a császári központban eltervezett program részeként épültek meg az őrtornyok, az építkezések évente haladtak előre a Duna mentén. Lásd ehhez legújabb bizonyítékként a Visegrád-Lepencén előkerült új építési feliratot: Gróf P.—Gróh: Visegrád. Római kori emlékek. Budapest 1997. 4—5.

${ }_{106}$ Ritka előfordulásuk, valamint alaprajzi hasonlóságuk és építési idejük miatt inkább rokoníthatók a patkóalakú tornyokkal. Véleményem szerint nem tárgyalhatók a félköríves tornyok felsorolt csoportjai között a köln-deutzi, illetve a haus bürgeli erődök tornyai (mindkettő Constantinus-kori, v.ö. CIL XIII 8502), amelyek valóságosan köralakúak, ugyanis a befelé ugró részükön a megkezdett kör folytatódik.

107 A keltezéseknél Lander: i. m.; S. Jones: Late Roman fortifications. London 1983 és Petrikovits, i. m. munkáit, illetve utóbbiak appendixét vettem figyelembe, csak eltérő, vagy újabb keltezés esetén térek ki az egyes táborokra, illetve városokra.

${ }^{108}$ P. Garmy —L. Maurin (ed.): Enceintes romaines d'Aquitaine. Bordeaux, Dax, Perigueux, Bazas. Documents d'Archéologie Française Nr. 53. Paris 1996. 69, 75-76.

${ }^{109}$ M. Amand-I. Eykens-Dierickx: Tournai romain. Diss. Arch. Gandenses V. 1960.

${ }^{110}$ Utóbbi tornyot poligonálisnak is szokták nevezni (Jones: i. m. 163), de alaprajzi sajátosságai miatt leginkább ehhez a csoporthoz lehetne sorolni: Lander: i. m. 185; Petrikovits: i. m. 211.

${ }^{111}$ A korábban Valentinianus uralkodására keltezett erőd valószínúleg korábbi (Lander: i. m. 276280, Jones: i. m. 153-154). Ezzel szemben újabban: H. U. Nuber: Das spätrömische Kastell von Alzey. Studien zu den Militärgrenzen Roms III. Stuttgart 1986. 235-243.

112 Aquitania. 69, 75-76.

${ }^{113}$ Johnson: i. m. 78—79, Maxfield: 49-50. 
Bavai (Diocletianus, vagy Constantinus-k.), ${ }^{114}$ Dax (Magnentius), ${ }^{115}$ Périgueux (IV. sz. elsố fele), ${ }^{116}$ Anse (IV sz.), Toul (300 körül), Boulogne-sur-mer (Carausius-I. Constantius-k.), ${ }^{117}$ Auxerre (késô Constantinus-k.), Nantes (IV. sz., de mindenképpen 275/76 után), ${ }^{118}$ Leon, Lucus Augusti, Caesaraugusta, Astorga, Iruna, ${ }^{119}$ Mont Sommerein (erődített hegyi telep-III. sz. vége), Tamuda (Africa-III. sz.), Dover (280-as évek), ${ }^{120}$ Lympne (275 után), ${ }^{121}$ Caistor (III. sz. vége), Pfyn (III. sz. vége-IV. sz. eleje), Altenburg bei Brugg (298 után), Kellmünz (Kr. u. 300), ${ }^{122}$ Ain Sinu II (III. sz. második fele), ${ }^{123}$ Jülich (III. sz. 2. fele), Moosberg (Kr. u. 259-280), Brittenburg (IV sz.?), ${ }^{124}$ Goldberg bei Türkheim (Constantinus-k.), Boppard (Constantinus-k.), Xanten (Constantinus-k.), ${ }^{125}$ Strasbourg (Constantinus-k.), Kreuznach (Constantinus-k.), ${ }^{126}$ Bitterne (340 után), ${ }^{127}$ Cuijk (késő Constaninus-k.-Valentinianus), ${ }^{128}$ Qasr Khabbaz (IV. sz. ?), ${ }^{129}$ Quasr Tell Brak (IV sz.), ${ }^{130}$ Wiesbaden (Heidenmauer, Valentinianus-k.).

${ }^{114}$ Mindkét csoportnál megfigyelhetô egy időrendi csúszás a városok, illetve a katonai erődök között (pl. az első és második csoportban a városokhoz tartozó oldaltornyok egy része még a tetrarchia előtt megépülhetett a $270-80$-as években. Mivel ez a jelenség máshol is megfigyelhetó jogosnak tartható Petrikovits azon elképzelése, mely szerint a városfalak, illetve tornyok előképül szolgáltak a katonai építkezéseknek (Petrikovits: i. m. 203). További félköríves oldaltornyokkal megépített galliai városok: Rennes, Bourges, Poitiers, Rouen, Le Mans, Evreux, Le Héraple, Tours, Metz. Valószínúleg ezek is a III. sz. 70-80-as éveire keltezhetók: A. Grenier: Manuel d'archéologie Gallo-Romaine. Vol 5. Paris 1931. 412-414, 418, 422-426, 435, 347-348, 550 .

115 Aquitania: 83-125.

116 Aquitania: 153.

117 Maxfield, i. m. 62-72.

118 Johnson: i. m. 77-78; Maxfield: i. m. 49 (275-76-os miliarium a falba beépítve!).

${ }^{119}$ I. A. Richmond: Five town-walls in Hispania citerior. JRS 21 (1931) 87-100. Legújabban: Th. Hauschild: Murallas de Hispania en el contexto de las fortificaciones del área del Imperio Romano. in: La ciudad en el mundo romano. Actas XIV. Congreso Internacional de Arqeología Clásica I-II. Tarragona 1994. 223-232 (270-310 közötti keltezéssel). A leoni tábor ásatója azonban jóval késóbbre, a következő századfordulóra keltezte az igen vastag (több, mint $5 \mathrm{~m}$ ) táborfalat és a tornyokat: A. Garcia y Bellido, Estudios sobre le legio VII Gemina y su campamento en Leon. in: Legio VII Gemina. Leon 1970. 569599, 575). A keltezéshez lásd még: P. Le Roux: L' armee romaine et l'organisation des provinces Iberiques d'Auguste a l'invasion de 409. Paris 1982. 391-392. A viták ellenére a III. sz. végi-IV. sz. elejei keltezés tünik biztosabbnak.

120 Johnson: i. m. 51-53; Maxfield: i. m. 148-150.

121 Johnson: i. m.: 53-56; Maxfield: i. m: 152-157. Dover és Caistor keltezéséhez és formájához: $D$. A. Welsby: The Roman military defence of the British provinces in its later phases. BAR BS 101. Oxford 1982, 52, 147, fig. 5, 22/9, 10/1

122 Mackensen: i. m.

123 Kennedy-Riley: i. m. 168-170.

${ }^{124}$ T. Bechert-W. J. H. Willems: Die römische Reichgrenze zwischen Mosel und Nordsee-küste. Stuttgart 1995. 96-98. Ezzel szemben: M. D. de Weer: Recent excavations near the Brittenburg. A rearrangement of old evidence. in: Studien zu den Militärgrenzen Roms III. Stuttgart 1986. 284-290.

${ }_{125}$ I. Moosdorf-Ottinger: Goldberg bei Türkheim. Münchner Beiträge zur Vor-und Frühgeschichte 24. München 1981.

${ }^{126}$ Lander: i. m. $280-82$.

127 Johnson: i. m. $141-142$.

128 Lander: i. m. 283, Bechert-Willems: i. m. 72-73.

${ }^{129}$ Kennedy-Riley: i. m. 212.

${ }^{130}$ Kennedy-Riley: i. m. 187-189. 
A harmadik, igen ritka csoportba a következók tartoznak: Tamuda (AfricaIII. sz.), Sarrebourg, Tokod (Valentinianus-k.), ${ }^{131}$ Lindenhof (Valentinianus-k.), Scarbantia (?), ${ }^{132}$ Bassianae (?). ${ }^{133}$

A minket érdeklő elsố toronytípus Pannoniában eddig egyedül a neve alapján tetrarchia-kori pilismaróti táborból volt ismert (Castra ad Herculem), amely az ásató Finály G. megfigyelése szerint késôbbi hozzáépítés volt. Ezért a tornyokat és magát a típust is Valentinianus, legfeljebb II. Constantius korára keltezték. ${ }^{134} \mathrm{Az}$ ennyire késôi keltezés ellen több érv is szól:

1. Az ásatás során másodlagosan felhasznált kőemlékek nem kerültek elő (Finály 1907, 55), ami egy késôbbi építkezésnél jószerivel kizárható volna.

2. Az erőd korábbi oldaltornyait megfigyelni nem lehetett, az elókerült egyetlen biztosan patkóalakú torony egy saroknál helyezkedik el. Nem megnyugtatóan tisztázott a korábbinak tartott tornyok alaprajza sem.

3. A típus párhuzamai jóval korábbiak, mint Valentinianus kora.

Mindezek alapján feltételeznünk kell - elfogadva az eddig csak az ásató által megfigyelt jelenséget, mely szerint a táborfalhoz a tornyokat másodlagosan építették hozzá -, hogy nem sokkal a tábor megépülte után, legkésóbb még a IV. sz. elsô harmadában került sor a tornyok hozzáépítésére.

Régóta ismert Rómer F. és Berkovics-Borota M. múlt századi felmérése a brigetioi legiostáborról. ${ }^{135} \mathrm{~A}$ tábor keleti, nyugati és déli oldalán a csak felszíni nyomok alapján (a kiszedett toronyfalak mélyedései alapján), de a keleti oldalon két torony falainak feltárása alapján félkörívalakú oldaltornyokat és körte alakú saroktornyokat rajzoltak be (Visy 1989, 53). ${ }^{136}$ Berkovics-Borota az említett két tornyon

131 Mócsy: i. m. (94. j.) 42.

132 A scarbantiai városfalakat a korábbi kutatások alapján a tetrarchia korára keltezték (Póczy K.: Scarbantia városfalának korhatározása. ArchÉrt 94 (1967) 137-153; eadem: Scarbantia. Sopron in the Roman period. Kecskemét 1977, 32-36), de újabban jogos kifogások merültek fel vele kapcsolatban. A kövek közti habarcsban talált Diocletianus érem csak terminus postquem lehet és a szokatlanul vastag falak is inkább a IV. sz. második felére való keltezést támogatják (Soproni: i. m. (11. j.) 146, Anm. 60; Tóth: i. m. (99. j.) 34, lj. 49). A kapuzatnál előkerült másodlagos faragott kőemlékek is a késóbbi keltezést támogatják.

${ }_{133}$ Antiquity 10 (1936) 475; Mócsy A.: Savaria utcarendszerének rekonstrukciójához — Zur Rekonstruktion des Strassensystems von Savaria. ArchÉrt 92 (1965) 35.

${ }^{134}$ Finály G.: Castra ad Herculem. ArchÉrt 27 (1907) 45-57; Soproni: i. m. (11. j.) 46-48. Korábban éppen Soproni vetette fel az éremforgalom alapján, hogy maga az egész tábor esetleg Constantinus idejében épült: S. Soproni: Der spätrömische Limes zwischen Visegrád und Esztergom. in: Limes Romanus Konferenz Nitra. Bratislava 1959. 131-143, 135. Az elókerült kevés érem alapján azonban éremforgalmat megállapítani lehetetlen, a legkorábbi Kr. u. 307-ból való volt: Cf. FMRU III (1999) 426, CommArchHung 2001, 230.

135 Rómer F.: A Pannonia területén Magyarországban fennmaradt néhány római várnáról. ArchKözl 3, 1862, 33-53, 45-49, 46-47, Berkovics-Borota M.: Ásatásom az ószónyi római táborban. ArchÉrt 6 (1886) 392-397; ArchÉrt 7 (1887) 30-38; Österreichische Milit. Zeitschrift 4 (1885) 177.

136 Visy: i. m. (43. j.) 53; Zs. Visy: Guide to the excursion on the ripa Pannonica. in: Excursion guide. 31st international symposium on archaeometry. Budapest 1998. 69; id.: A ripa Pannonica Magyarországon. Budapest 2000, 31. 
kívül még 11 másikat figyelt meg, míg Rómer 10 félköríves oldaltornyot mért fel, de rajza szerint a kaputornyok is félkörívesek voltak, amelyet azonban a későbbi ásatások nem erôsítettek meg, továbbá kiugró oldal- és saroktornyokat sem találtak. Mindezek miatt a tornyok létével kapcsolatosan komoly kétségek merültek fel. ${ }^{137}$ Ennek azonban ellentmond az a tény, hogy két, egymástól független felmérés hasonló alaprajzot állapított meg, továbbá a két toronynál is biztosan megfigyelt kiugró toronyfalak aligha lehettek légből kapottak. A korábbiak alapján készült Visy-féle rekonstrukció alapján egy-egy oldalon négy-négy torony volt található. Ezek távolsága egymástól akkora volt (több, mint $60 \mathrm{~m}$ - a Rómer által mért távolság legtöbbször 70 lépés!), hogy a Paulovics által vizsgált északkeleti sarokba nem eshettek bele. Ez alapján a táborhoz egy még ismeretlen periódusban kiugró félköríves tornyokat építhettek, IV. sz. közepére, második felére keltezhető hozzáépítéseket, elfalazásokat (legyező alakú torony, kapuelfalazások) pedig nem ismerünk. A tábor 3. építési periódusát általában Constantinus idejére keltezik. ${ }^{138}$ Sajnos jelen ismereteink alapján nem dönthetô el, hogy az oldaltorony melyik csoportunkhoz tartozik, de két tetrarchia-kori aranyéremlelet alapján (a legkésôbbi 293-ból) feltételeznünk kell a tábor ekkori pusztulását, majd ezek után való átépítését. ${ }^{139}$ A felmérés alapján a tornyok hasonló méretúek lehettek a szentendreihez. Rómer öt ölnyi szélesnek mérte a tornyokat, a falaik szélességét pedig $1-1,5$ ölnyinek becsülte.

Félköríves tornyokat ismerünk még továbbá Almásfüzitő auxiliaris táborából, ahol a korábban leírtakkal szemben a portae principales, valamint a porta decumana elfalazása nem patkó, hanem félköríves alakú. ${ }^{140} \mathrm{Az}$ elfalazás az ásató feltételezése szerint a IV. sz. elején, Constantinus uralkodása alatt történt párhuzamosan a legyezô alakú saroktornyok megépítésével. A biztosan keltezhető pannoniai párhuzamok (a legyező alakú saroktornyok esetében) alapján jogosan feltételezik, hogy az átépítés II. Constantius, vagy Valentinianus uralkodása alatt történt. ${ }^{141}$ Az elfalazás után a volt kapuk tulajdonképpen félköríves alakú oldaltornyokká váltak, amelyek formája alapján a mi 2. csoportunkba sorolhatók be, ${ }^{142}$ mivel a táborfal vonalában történt a táborfal tuladonképpeni elfalazása, amely egyúttal az oldaltorony hátsó falaként is szolgált. A tornyok mérete szintén hasonló a szentendreiéhez.

${ }^{137}$ Paulovics I.: Funde und Forschungen in Brigetio (Szőny). DissPann II/11 (Laureae Aquincenses II). Budapest 1941. 118-164, 162. A szintén félkörívesnek vélt kaputornyok bizonyosan négyszögletesek. Berkovics-Borota második ArchÉrt publikációjában megjegyezte (ArchÉrt 7 (1887) 33), hogy az általa „,kiásott toronyalapfalak csakugyan a tervben kijelölt helyen voltak, de alapjuk nem köralakú, hanem derékszögú volt”. Az elsố cikkében közölt alaprajz szerint a keleti oldal két oldaltornyának indítását ásta részben meg, a tornyok külső részét azonban nem kutatta, ezért nem zárható ki, hogy félköríves (vagy patkóalakú?) oldaltornyok indításait találta meg.

${ }^{138}$ L. Barkóczi: Brigetio. in: Der römische Limes in Ungarn. 35.

${ }^{139}$ Barkóczi L.: Brigetio. Budapest 1951. 16, 27.

${ }^{140}$ E. Biró: Azaum. in: Der römische Limes in Ungarn. 39; Visy: i. m. (43. j.) 57-58; Jones: i. m. 182. (43. j.) 53).

${ }^{141}$ Gabler - Lórincz: i. m. 101. Visy Zs. szintén I. Constantinus korára teszi az átépítést (Visy: i. m.

${ }_{142}$ Emiatt nem zárható ki a constantinusi keltezés sem, bár a II. Constantius kori átépítés nem mond ellent a csoport többi tagjáénak. Leginkább az utóbbi tűnik számunkra elfogadhatónak. 


\section{Összefoglalás}

Diocletianus pannoniai építkezéseit a rendelkezésre álló adataink segítségével viszonylag pontosan keltezhetjük a 294. év utáni periódusra. A következő adatok bizonyítják az erre az időre való keltezést:

1. Hydatius Fastijának adata a barbaricumi táborok építéséról Sarmatiában 294-ben, amely a forrás felhasználójának tévesztése miatt inkább 293-ra keltezhetô.

2. A tetrarchák (Diocletianus és Maximianus) 294-es építkezéseiket ezüstérem-típusaikon is megörökítették, amelyek közül a római verésú körirata: VICTORIAE SARMATICAE (a többi: PROVIDENTIA, vagy VIRTUS), valamint a hátoldali táborkapu-ábrázolás alighanem csak a pannoniai erődépítésekre vonatkoztatható. ${ }^{143}$

3. Diocletianus a 294-et megelőző időszakban kisebb megszakításokkal ugyan, de folyamatosan Pannoniában, Sirmiumban, 293 novemberében pedig Lugióban tartózkodott. ${ }^{144}$

4. A két brigetioi aranyérem- és kincslelet záróverete 293-ból való. ${ }^{145}$ A két lelet minden bizonnyal a tábor akkori pusztulásával hozható kapcsolatba. A felette található réteg már a tábor 3. építési periódusából való. ${ }^{146}$ Talán erre a korra keltezhetôek a tábor feltételezett félköríves oldaltornyai.

5. A hosszas ittlétének oka az az elhúzódó szarmata háború lehetett, amelynek a végét a Kr. u. 294. év jelentette, amikor Diocletianus harmadszor, Galerius elóször lett Sarmaticus. ${ }^{147}$

6. A legvalószínúbben 292-re vagy 293 elejére egészíthető ki (a caesarok hiánya miatt) a Diocletianus és Maximianus Augustusok (Nominativusban) által Iuppiter Optimus Maximus számára állított mikebudai felirat (CIL III 10605a), amelyet a legvalószínúbb módon a R. Egger-féle kiegészítés (ob devictos Sarmatas) alapján egy

${ }^{143}$ RIC VI. 354, Nr. 43; Budapest története I. Budapest 1942. 674; Nagy: i. m. (12. j.) 101; Mócsy: i. m. (12. j.) 269. Óvatosságra int: Tóth: i. m. (5. j.) 71, Anm. 20.

${ }^{144}$ A kor történetéhez nézd: Mócsy: i. m. (12. j.) 268-269; id.: A tetrarchia kora. in: Pannonia régészeti kézikönyve. Budapest 1990. 46, PWRE VII (1948) 2438-2440. A tetrarchák utazásaihoz: Th. Mommsen: Gesammelte Schriften II. Berlin 1905. 267-.

${ }^{145}$ Hampel J.: Egy bregetioi éremkincs. ArchÉrt 11 (1891) 350-352 (=Numismatische Zeitschrift 18 (1891) 85-87); R. Alföldi M.: Aranykincslelet Brigetióból a III. század végéról. Numizmatikai Közlemények 48-49 (1949-50) 5-9.

${ }_{146}$ Radnóti A.: A magyar történeti Múzeum régészeti Tárának ásatása Szőnyben (1946). Magyar Múzeum (1946) 91.

${ }^{147}$ Diocletianus Sarmaticus (Maximus) jelzői többségét 285-294 vette fel: I: Kr. u. 285, II: 289, III: 294, IV: 299-300: cf. D. Kienast: Römische Kaisertabelle. Grundzüge einer Kaiserchronologie. Darmstadt 19962. 262—265, 264; T. D. Barness: Phoenix 30 (1970) 171—. Galerius: I: 294, II: 299—300, III: 302?, IV: 306-307, V: 310: Kienast: i. m. 279-282. 
győztes szarmata hadjárat után állítottak. ${ }^{148}$ Az építési tábla korábbi feltételezésekkel szemben aligha lehet egy barbaricumi tábor építési felirata, ${ }^{149}$ hanem sokkal inkább egy aquincumi szentély (át)építését örökíthette meg, amelyet egy hadjárat befejeztével állított a két augustus. Az augustusok nominativusai a személyes jelenlétet feltételezhetik az Aquincum környéki limes mentén. Utóbbi azért is lényeges, mert ha valójában 293-ra vonatkozik Hydatius adata, akkor Contra Aquincum építése akár a császár személyes jelenlétében is folyhatott.

7. A már említett ôrtorony építési programot úgy túnik a tetrarchia-kori mérföldkövek állítási ideje alapján nem alaptalanul tették valamivel késóbbre (Visy: i. m. (3. j.) 172-174). A kevés, ebből az idôszakból származó pannoniai mérföldkő többségét ugyanis 305-6 körül állították.

8. 293. március 1. után Galerius caesar lett, ${ }^{150}$ uralma területéül Illyricumot kapta. Ennek ellenére Diocletianus még majdnem másfél évig a tartományban (fóleg Sirmiumban) maradt, ami a harcok és a helyzet súlyosságát jelzi. ${ }^{151}$ Diocletianus 293 november 5-én két rendeletét is Lugio (Dunaszekcső) táborában bocsátotta ki (Cod. Iust. IX, 20, 10-11), ${ }^{152}$ tehát nem csak Dél-Pannoniában tartózkodott, hanem az alsó-pannoniai limesszakasz északi részén is. A háború pusztításai az éremleletek alapján a brigetioi legiostábort is érintették és valószínúleg Kelet-Pannonia többi kisebb auxiliaris táborát is elérték. A károk kijavítására az ezutáni időszaktól kerülhetett sor, a tornyok egységes építési kampányra utalhatnak. Ez minden bizonnyal még az augustus személyes jelenlétében megkezdődött.

9. Pannonia ebben a periódusban végrehajtott közigazgatási átszervezése (Kr. u. 296?) is jelentôs változásokat kellett, hogy hozzon, mivel az új tartomány, Pannonia II legiok nélkül maradt, amelyet a két új legio létrehozásával kellett ellensúlyozni. ${ }^{153} \mathrm{Az}$ új csapattesteket újonnan létrehozott táborokban kellett elhelyezni.

148 Alföldi A.: Epigraphica IV. ArchÉrt (1941) 30-39, 37-38; R. Egger: Ein zweimal beschriebener Weihestein. JhÖAI 35 (1943) 21-28. A lelőhelyről: A. Mócsy: Ein spätantiker Festungstyp am linken Donaufer. in: Roman Frontier Studies 1969. Eighth International Congress of Limesforschung. Cardiff 1974. 191-196, 196, Anm. 11=Pannonien und das römische Heer. Ausgewählte Aufsätze. MAVORS VII. Sturrgart 1992. 246-251, 251, Anm. 11. Érdekes, hogy Soproni S. is erre az évre keltezi az építkezések megkezdését (Soproni: i. m. (11. j.) 194).

${ }^{149}$ A. Mócsy: Das letzte Jahrhundert der römisch-barbarischen Nachbarschaft im Gebiete des heutigen Ungarn - A római-barbár szomszédság utolsó évszázada hazánk területén. Cumania 4 (1976) 84. Azért sem lehet barbaricumi tábor építési felirata - Mócsy elgondolása -, mivel a felirat majdnem biztosan 294 előtti. Valószínúleg igaza van R. Eggernek, aki szerint inkább egy szentély helyreállításról lehet szó: rest., mivel egy szentély építésénél valószínúbb a hosszabb megszövegezés.

${ }^{150}$ Kienast: i. m. 279-282.

${ }^{151}$ O. Seeck: Geschichte des Untergangs der römischen Welt I. Berlin 1910. 33; M. Mirković: Sirmium - its history from the I century A. D. to 582 A. D. in: Sirmium I. Beograd 1971. 36.

152 A romlott helynév emendatiojához: $R$. Fröhlich: AEM 14 (1891) 51.

${ }^{153}$ J. Fitz: Die Verwaltung Pannoniens in der Römerzeit III. Budapest 1994. 1177-1181. 